\title{
The use of stone at Ohalo II, a 23,000 year old site in the Jordan Valley, Israel
}

\author{
Polina Spivak ${ }^{1}$, Dani Nadel ${ }^{2}$ \\ 1. Israel Antiquities Authority, Israel. Email: bobrn1@yahoo.com \\ 2. The Zinman Institute of Archaeology, The University of Haifa, Israel. Email: dnadel@research.haifa.ac.il
}

\begin{abstract}
:
A wide range of stones were found at the 22,000-24,000 year old lakeshore camp of Ohalo II, the Sea of Galilee, Israel. The well-preserved camp includes the floors of six brush huts, several open-air hearths, a grave, a midden, and small installations. Stones were found in all excavated loci. These include a small assemblage of basalt and limestone tools, among which bowls, grinding implements and weights are the most common. Use-wear analysis supports the identification of the grinding tools, suggesting that cereals were indeed processed with them, but not in an intensive manner. The presence of thousands of cereal grains as well as several sickle blades accord well these finds. Bowls were all shallow and only their fragments were found. Weights were likely used as fishing net sinkers. Limestone and basalt flakes indicate local knapping. Basalt and limestone fragments, shattered from heat, were abundant in all the excavated loci. Their original use is yet to be verified, but their shattering from heat was affirmed by a series of experiments. Stones were also used as wall supports. The range of types, contexts and activities reflected by stone tools and natural stones is unprecedented in other contemporaneous sites in the southern Levant.
\end{abstract}

Keywords: Ohalo II; ground stone tools; Late Upper Palaeolithic; submerged site; preservation

\section{Introduction}

This work discusses the wide variety of limestone and basalt tools, manuports and natural stones used at the Ohalo II fisher-hunter-gatherers' camp (Figure 1). The site is well-preserved with a wide range of structures, hearths and stone installations (Nadel 2002). As such, the study of the variety of stones used at the site, with ground stone tools on the one hand and construction stones on the other provides new insights into camp life, mundane activities and even symbolic behavior.

We are aware of the fact that the inclusion of manuports and especially construction stones appears to be somewhat unusual for such a ground stone-focused volume. However, when regarding Levantine pre-Natufian Late Pleistocene sites, stone features are rarely found and presented, and even manuports are hardly described or discussed. Furthermore, some of the Ohalo II stone features include ground stone implements. We thus took the broad approach and addressed all aspects of stone use at the site for this paper. Thus, the goals of

Published by the School of History, Classics and Archaeology, University of Edinburgh ISSN: 2055-0472. URL: http://journals.ed.ac.uk/lithicstudies/

This work is licensed under a Creative Commons Attribution 2.5 UK: Scotland License. 
this paper are to characterize and provide preliminary analysis results of the ground stone tools, the production debitage (basalt and limestone flakes), stones used in installations, and, finally, the large assemblage of fire-cracked stones. Such a combination of analyses is rarely found in studies of Levantine prehistoric sites.

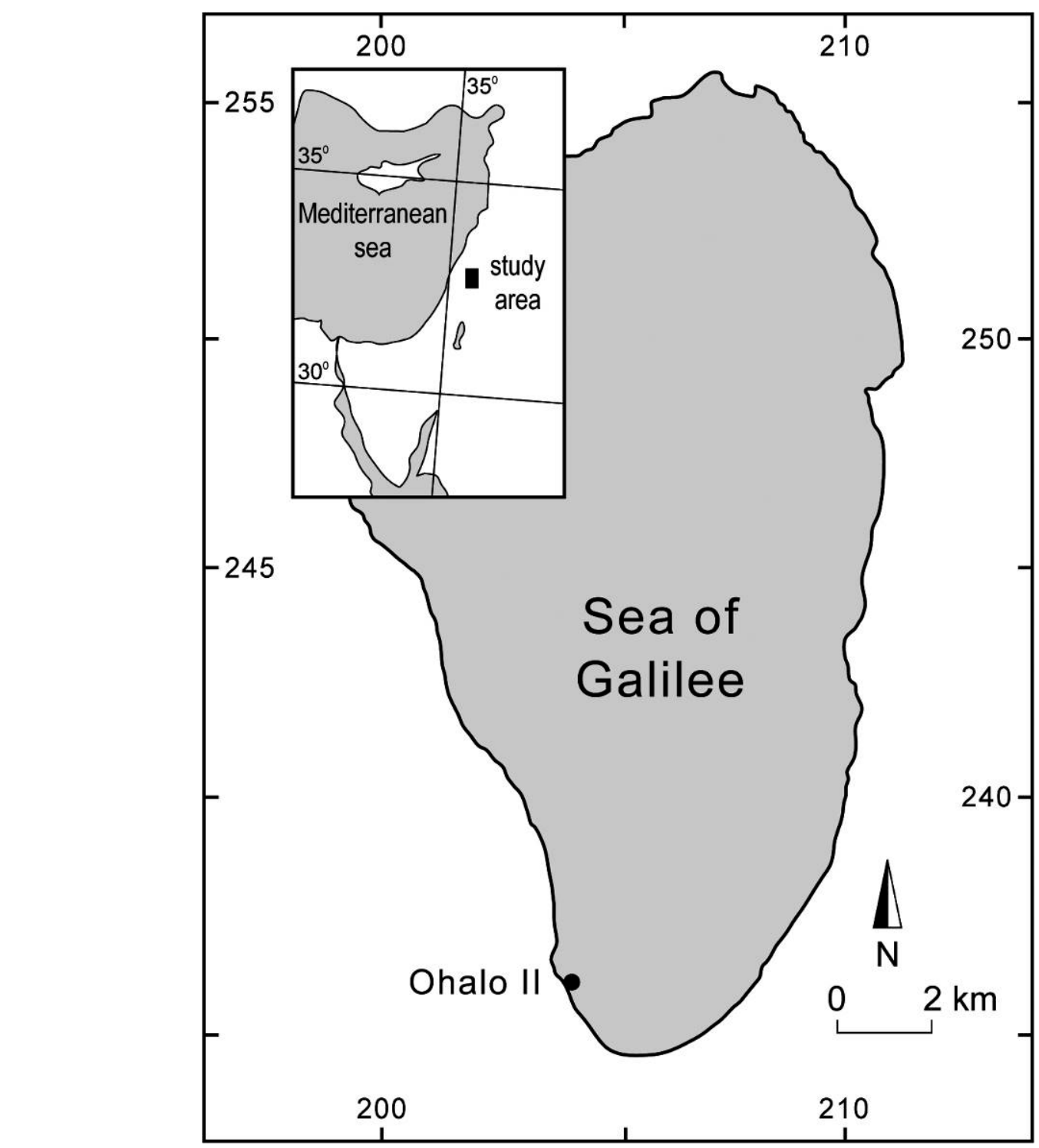

Figure 1. Location map of Ohalo II.

The Ohalo II site is located on the southwestern shore of the Sea of Galilee. It was first found when the water level dropped due to droughts and heavy pumping. Excavations revealed the remains of six brush huts, a grave, a pit, six concentrations of hearths, a stone installation and a dumping zone (Figure 2) (Nadel et al. 2004). The contours of the brush hut walls were clearly visible during excavation. These are the oldest ever found with identified species used for wall construction, including Tamarisk, Oak, shrubs and weeds (Nadel \& Werker 1999). The anthropogenic fill on the brush hut floors was dark and rich with material remains, while the bedrock lacustrine deposits were very poor in archaeological finds. Preservation was such that even grass bedding was well preserved on the lowest floor of the largest brush hut (Nadel et al. 2004). 


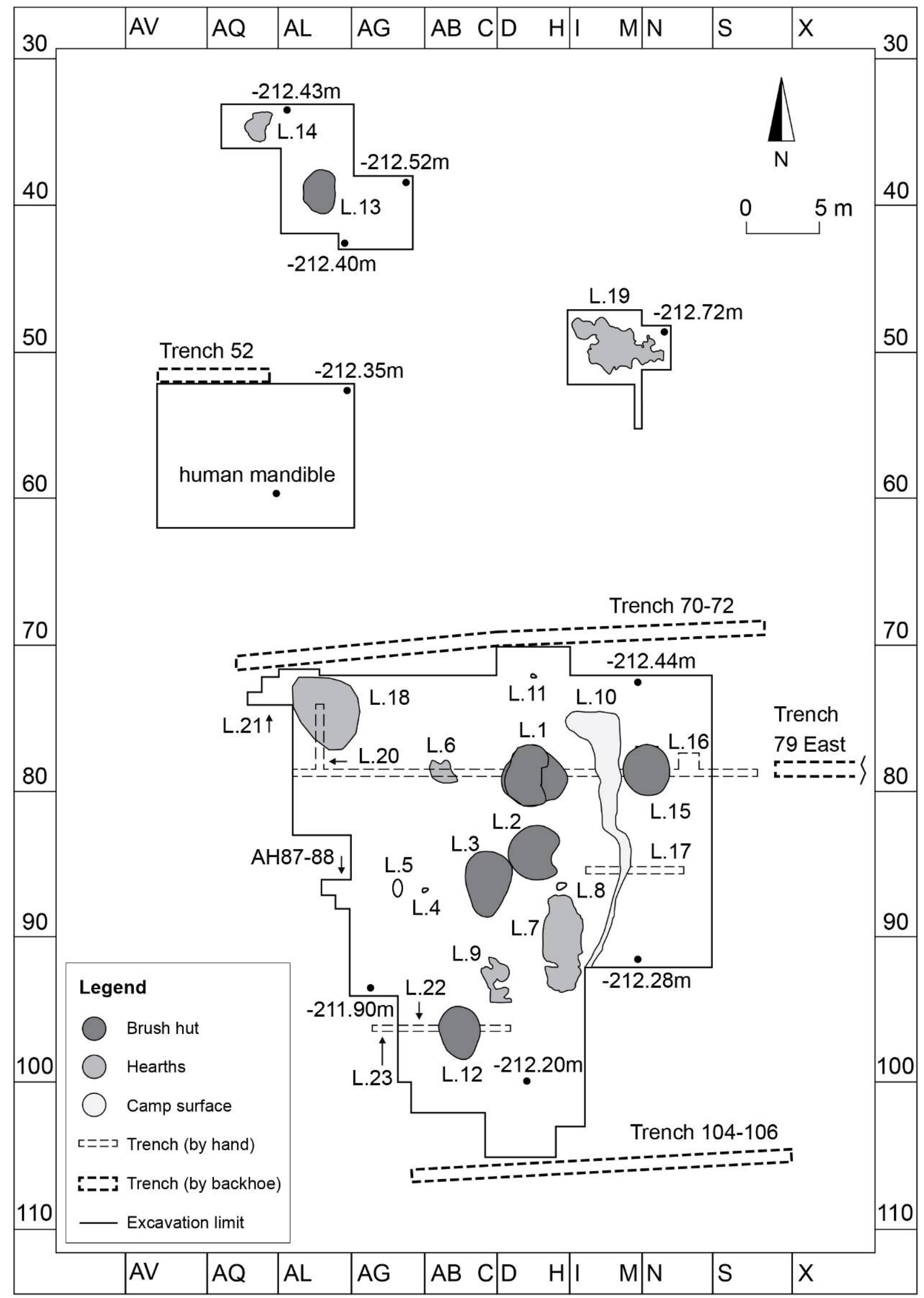

Figure 2. Plan of the Ohalo II site. 
Most loci were directly dated by several ${ }^{14} \mathrm{C}$ readings, indicating that the site was occupied between 22,000-24,000 cal BP (Nadel et al. 1995; 2001; 2006). The finds at the site include a wealth of plant remains such as cereals, legumes and other edible seeds and fruit (Weiss et al. 2008; Snir et al. 2015a; 2015b). Also very common were flint artifacts and mammal, fish and bird bones (Nadel et al. 2004; Rabinovich \& Nadel 2005). Additional finds include wood implements (Nadel et al. 2006), shell beads and bone tools.

\section{Methods}

Stones are literally absent in the lacustrine bedrock sediment in which the site is located (Tsatskin \& Nadel 2003). However, during excavation many hundreds of limestone and basalt specimens were found in each of the large loci, totaling 20,872 stones (Spivak 2008). Apparently, all were brought to camp (from the adjacent channel of the Yavne'el creek only tens of meters away, and the nearby beaches) and used on-site in one way or another. The finds range in size from a few $\mathrm{mm}$ to over $40 \mathrm{~cm}$ in length. Thus, it became possible to analyze all stone remains from all excavated loci.

The entire stone assemblage was first sorted by raw material, and basalt specimens (87\%) outnumber limestone (12\%) and unidentified specimens (1\%). Since pebbles and boulders of both basalt and limestone were available nearby, these frequencies clearly reflect human choice. In the second step, size sorting took place for each raw material. Four size groups were defined ( $<15 \mathrm{~mm}$, between $15-30 \mathrm{~mm}$, between $30-50 \mathrm{~mm},>50 \mathrm{~mm}$ ). In most loci the smallest stone specimens $(<15 \mathrm{~mm})$ are the most common, in both raw materials. A sample $(n=1,712)$ of basalt and limestone specimens larger than $30 \mathrm{~mm}$ was separated for further observations (Spivak 2008) and the discussion below is based on this sample.

On another level, all stones found at the site, regardless of raw material and size, were divided into major categories: A) ground stone tools; B) flakes (likely production waste); C) pebbles; D) stones used in construction; E) fragments, mostly fire-cracked. Each of these categories was studied independently of the other categories.

The major distinctions were based on morphological and techno-typological parameters, with ground stone tool identification and characterization following the works of Adams (1999; 2002: 11-18), and Wright (1991; 1992a; 1992b) who already studied stone assemblages from 21 Epipalaeolithic to Chalcolithic sites in the Levant. Flakes were defined as such if they had a bulb of percussion or previous dorsal scar(s). Fragments were sorted according to raw material and size. However, as many basalt fragments seemed to be the result of heat shattering, we conducted experiments where basalt stones were exposed to fire (see below).

\section{Data results}

\subsection{Ground stone tools}

The Ohalo II stone tools and tool fragments were divided into five major types, namely, bowls, grinding tools, weights, multiple tools and varia (Figure 3). Tools were found in all the excavated loci (Table 1). The general frequencies of complete tools and tool fragments are nearly identical. The most prolific locus was Brush Hut 12, with 15 specimens, and in total the six brush huts yielded 40 ground stone tools, with an average of 6.7 objects per hut. All other loci have isolated specimens, except for Loc. 4 which is a stone feature composed of ground stone tools. 


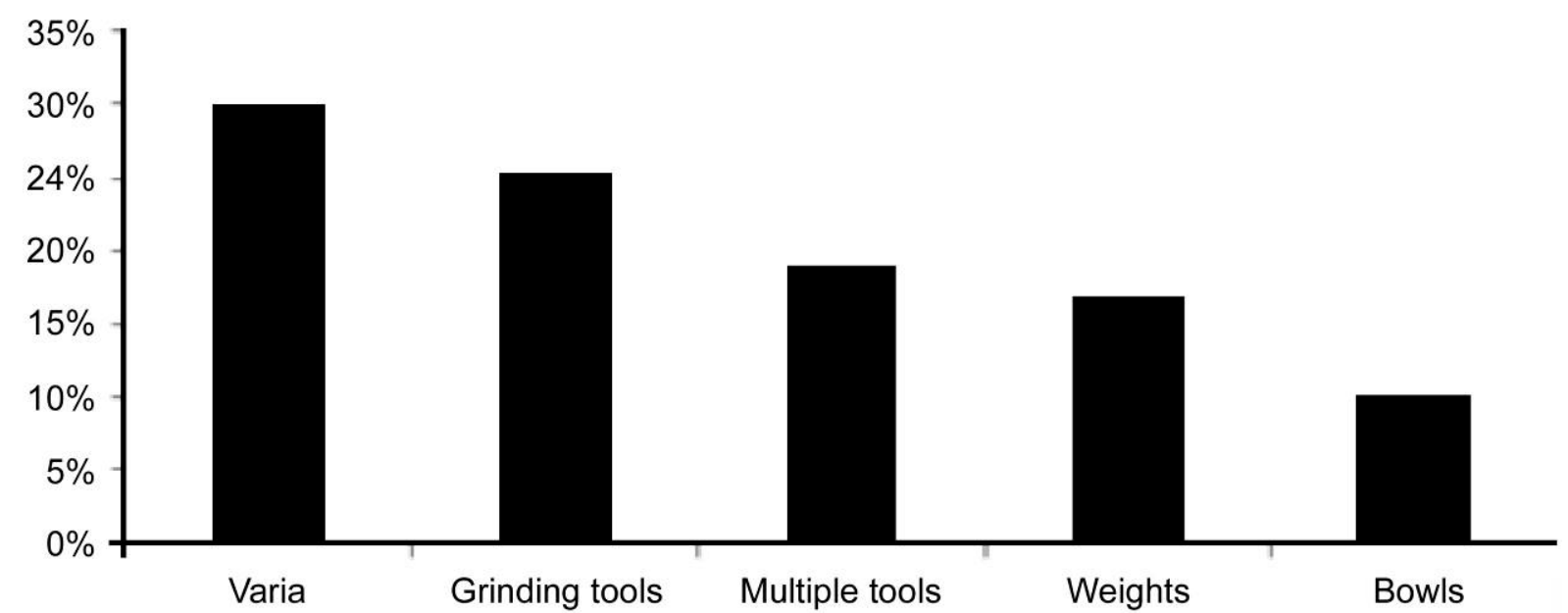

Figure 3. Frequencies of the five main tool categories found at the Ohalo II loci ( $n=71)$, by descending order.

Table 1. Frequencies of the five major tool types according to loci.

\begin{tabular}{|c|c|c|c|c|c|c|c|c|c|c|c|c|c|c|c|}
\hline Tool type & 1 & 2 & 3 & 4 & 10 & 12 & 13 & 14 & 15 & 18 & 19 & 20 & 22 & 23 & Total \\
\hline Bowls & & & 1 & & & 2 & 3 & & & 1 & & & & & 7 \\
\hline Grinding tools and querns & 1 & & & 11 & & 1 & & 1 & & & & 1 & 1 & 1 & 17 \\
\hline Multiple tools & 2 & 1 & 3 & & & 4 & 1 & 1 & & & & & & 1 & 13 \\
\hline Weights & 2 & 1 & & & 2 & 1 & 4 & 1 & & 1 & & & & & 12 \\
\hline Varia and fragments & 3 & & 1 & & 1 & 7 & 1 & 2 & 1 & 2 & 1 & 3 & & & 22 \\
\hline Total & 8 & 2 & 5 & 11 & 3 & 15 & 9 & 5 & 1 & 4 & 1 & 4 & 1 & 2 & 71 \\
\hline
\end{tabular}

\subsubsection{Bowls}

Bowls required the greatest investment at Ohalo II, in terms of workmanship and quality of the finished product. They were usually shaped with care by intensive, accurate pecking and smoothing of both internal and external faces. There are 11 bowl fragments, 9 of basalt and 2 of limestone, representing together 7 broken bowls (no complete bowls were found; Table 2).

Table 2. Bowl fragments data.

\begin{tabular}{lcccccc}
\hline & & & & Thickness & & Remarks \\
\hline 3 & Brush hut & Hard limestone & Fragment & 5 & Burning signs & Recime, side, rim \\
12 & Brush hut & Fine basalt & 3 fragments & 4 & - & Base, side \\
12 & Brush hut & Fine basalt & 2 fragments & 6 & - & Base \\
13 & Brush hut & Fine basalt & Fragment & 4.5 & - & Base, side, rim \\
13 & Brush hut & Fine basalt & Fragment & 5 & - & Base \\
13 & Brush hut & Soft limestone & Fragment & 1 & - & Base, side, rim \\
18 & Open-air & Fine basalt & 2 fragments & 3 & + & Base \\
\hline
\end{tabular}

All bowls except one (from Loc. 13, see below), share similar characteristics. Based on two wide rim fragments, the larger bowls had a diameter of ca. $30 \mathrm{~cm}$; all were round or semiround. The depth of most bowls did not exceed $4 \mathrm{~cm}$ and the angle between the rim and the inner (working) surface was wide and smooth. All preserved working surfaces contain macroscopically visible use-wear of protracted striations reflecting a longitudinal motion, probably related to grinding. 
The smallest bowl was made of soft limestone (Figure 4). The fragment includes a base, a wall and a rim. It is sub-rectangular in shape, just under $5 \mathrm{~cm}$ in each direction. The rim is low and relatively thick, while the base is thin, in some parts $<1 \mathrm{~cm}$. The inner face is covered by deep and shallow incisions. They are present in two main directions. Most of the inner face is covered by incisions perpendicular to the rim, though their depths and distances are not highly organized. At the junction of the rim and the base there are incisions following the circumference of the base.
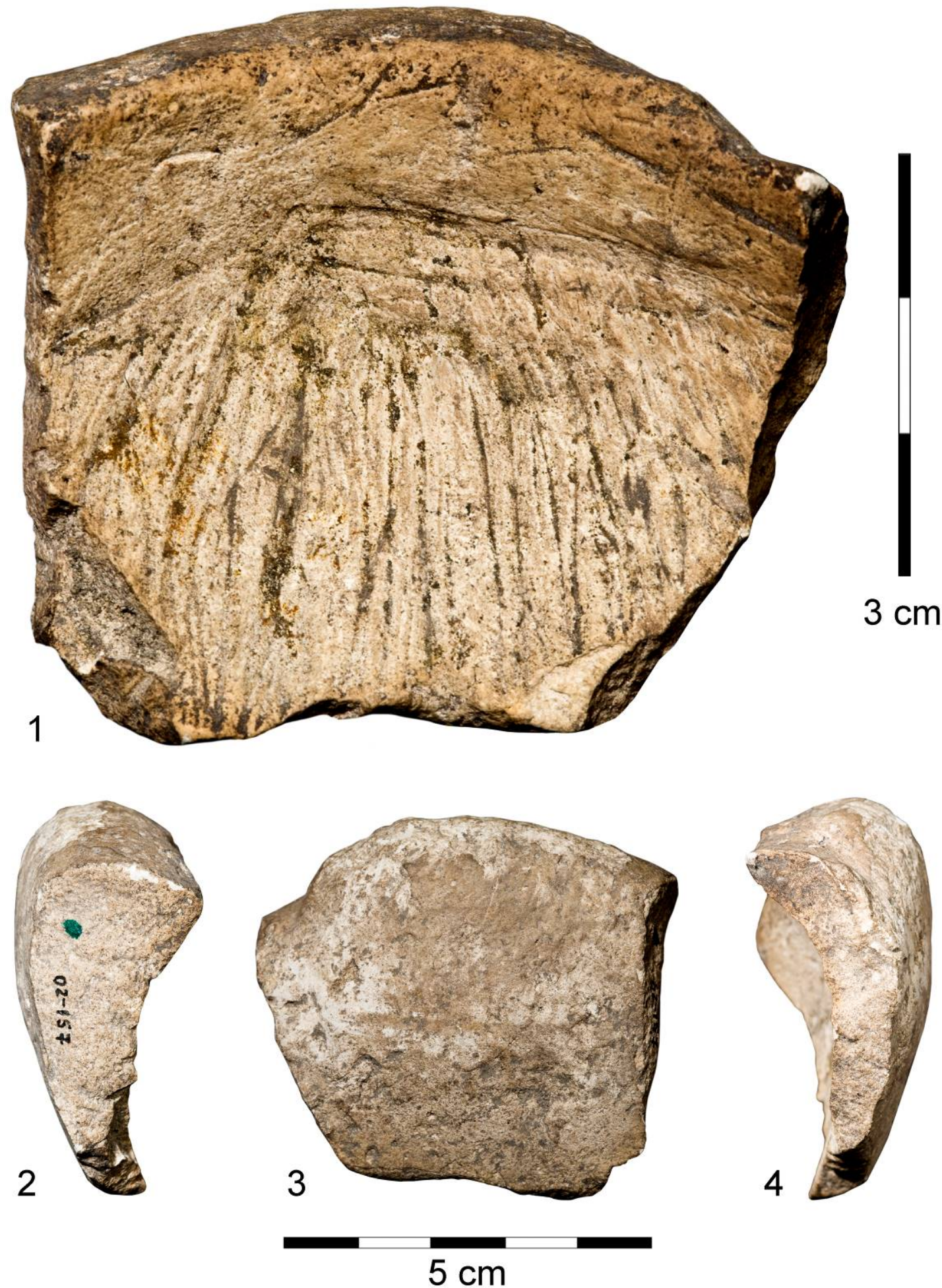

Figure 4. A soft limestone bowl fragment from Loc. 13. 1) top view; 2, 4) profiles; 3) bottom view. 
There are also some on the rim, inside, though their density is lower than both cases described above. No similar incisions are present on the outer surface. Likely, they reflect the manufacturing process; in such a case no smoothing or grinding work took place later. However, they could have also been made deliberately before discard. Use-wear analysis suggests the object may have been used for liquids (Dubreuil \& Nadel 2015). Some scars around the broken sides may indicate deliberate breakage of the bowl. It was found face down on the floor of Brush Hut 13, with no similar fragments on that floor or elsewhere at the site (Nadel 2003: fig. 12).

Another limestone bowl fragment was found in a similar setting on the floor of Brush Hut 3, also face down and without conjoinable fragments. This bowl was much larger, and the retrieved fragment is ca. $15 \mathrm{~cm}$ long, rectangular in general shape and up to $5 \mathrm{~cm}$ thick (Figure 5). The inner profile is shallow, though the rim was not preserved. The inner face is densely incised by many delicate lines (striations), mostly perpendicular or diagonal to the rim. These, again, indicate that the implement was not used in any grinding or pounding manner after the incisions were made. Somewhat similar striations were found on a $10 \mathrm{~cm}$ long limestone cobble from Ein Aqev (Marks 1976: fig. 9.28, bottom).

In summary, only two bowl fragments with dense incisions were found at the site. Both are isolated fragments with no conjoinable pieces. Both were made of limestone, heavily incised (though in different manners), not used for grinding and pounding after the incisions were made, and buried face down in a floor of a brush hut. These similarities and repeated patterns seem far from random in our eyes. We would rather advocate a symbolic behavior of which the social context is unknown. In support, we draw upon several ethnographic studies, where such behavior may have been intended to release the spirit from an object or to express compassion for, or prevent revenge from, a deceased person (e.g., Adams 2008; Dubreuil \& Nadel 2015). As shown by Wright (2014) for Holocene archaeological cases, intentional breakage of such tools during 'potlatch-type' events may be locale-specific, and their discard and breakage may be correlated with house abandonment. Many examples of none conjoinable fragments from the Neolithic through Bronze Age sites of the Balkan were used as evidence for deliberate breakage, as well as the distribution of the fragments among relatives and thus their deposition in different sites (e.g. Chapman 2000; Chapman \& Gaydarska 2007). Such events may have occurred following the death of a person.

However, there are additional bowl fragments at Ohalo II, some of which may also be viewed as the outcome of deliberate breakage. For example, a conjoined set from Loc. 12 includes three basalt fragments of a broken bowl (Figure 6). The thickest part was at the rim $(4.5 \mathrm{~cm})$. Both inner and outer surfaces were shaped to form a regular symmetrical profile. No incisions similar to those observed on the two limestone bowls were found here. The two breakage lines are more-or-less perpendicular to the rim, and they look as if they come from the same point somewhere in the middle of the bowl. This may indicate one major blow that cracked the implement into several pieces. Similar to the previously described bowl, this was also a large vessel, of similar dimensions.

Another example of refitting includes two basalt fragments from Loc. 12 (Figure 7). Both fragments have irregular shapes; they are from the base of a large shallow bowl, and no rim was preserved. Heavy incrustations are present on one fragment. Together they are ca. $17 \mathrm{~cm}$ across, indicating that the complete vessel was much larger. The preserved parts are $4-5 \mathrm{~cm}$ thick. The fragment with incrustations was flaked, perpendicular to the base axis (Figure 7). The most obvious are two adjacent similar scars, $2 \mathrm{~cm}$ across and $1.5 \mathrm{~cm}$ long.

Altogether, there are actually 7 bowls represented in the Ohalo II assemblage. The basalt bowls range in thickness between $3 \mathrm{~cm}$ and $6 \mathrm{~cm}$ (Table 2), while there is one thick and one thin limestone bowl. 

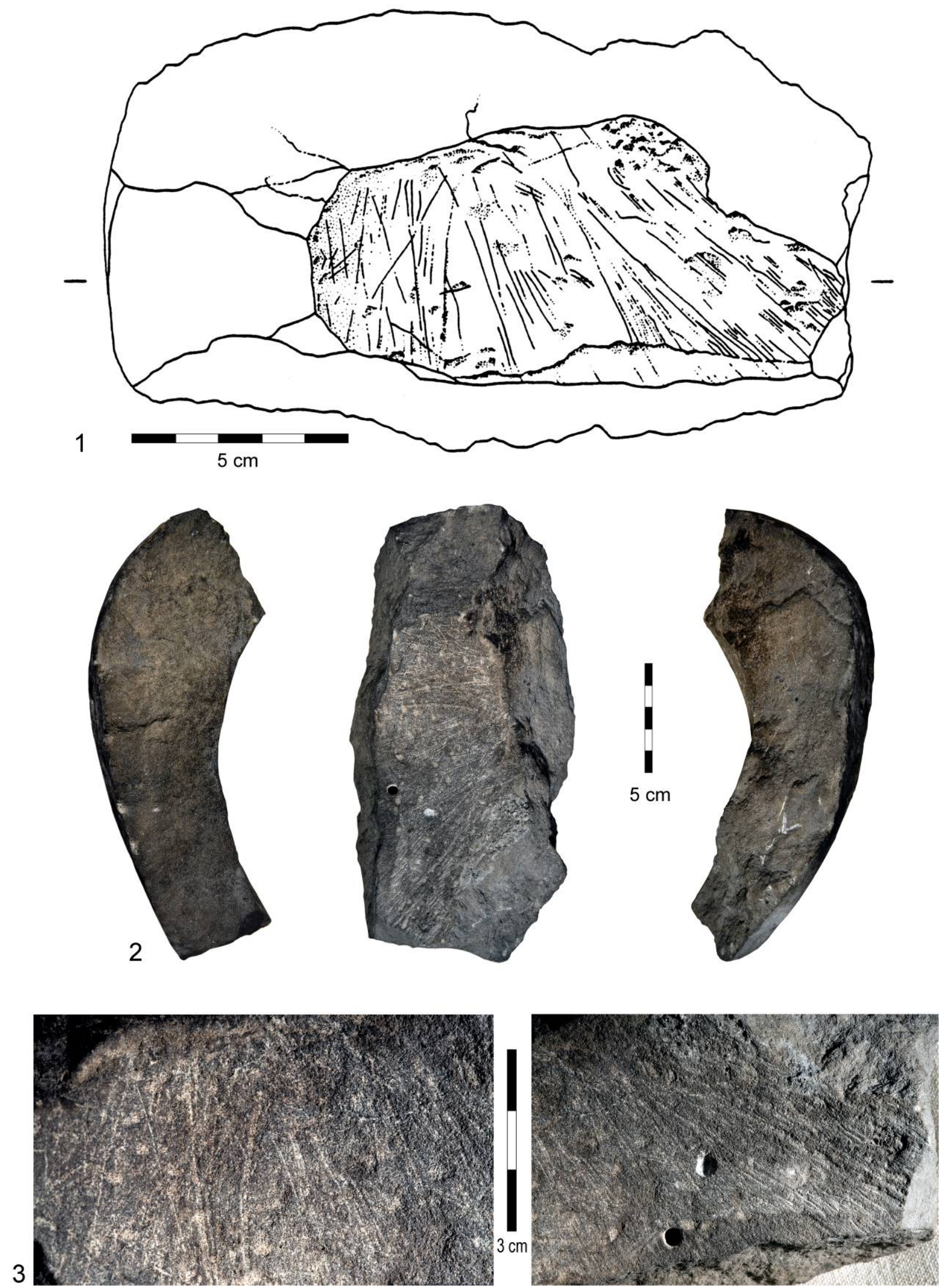

Figure 5. A limestone bowl fragment from Loc. 3. 1) drawing of inner face; 2) top view and two profiles; 3) close-up views of the incisions on the inner face. 

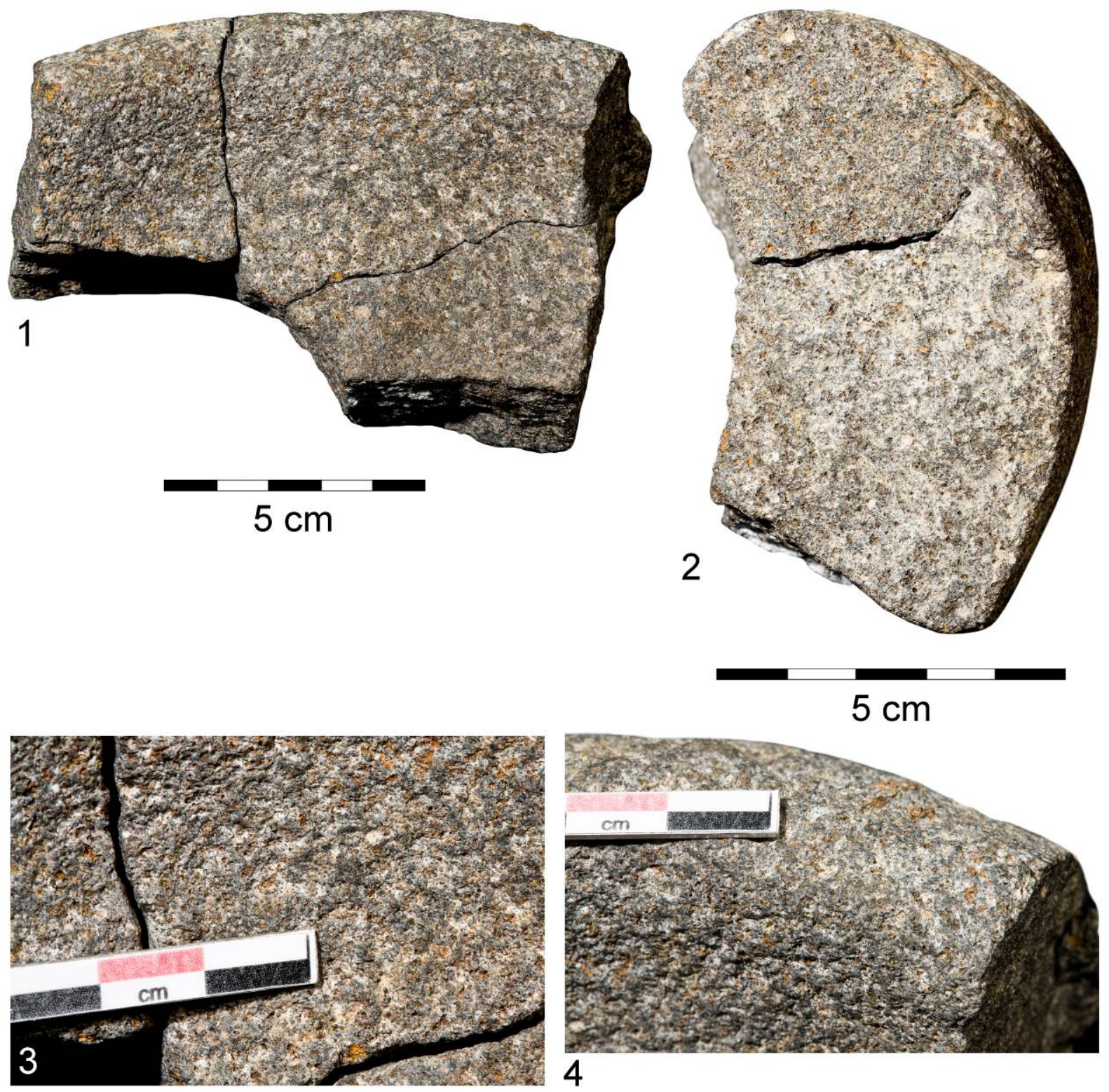

Figure 6. Three refitted fragments of a basalt bowl, Loc. 12. 1) top view; 2) the smooth regular profile; 3) closeup view of the base; 4) close-up view of the rim. 

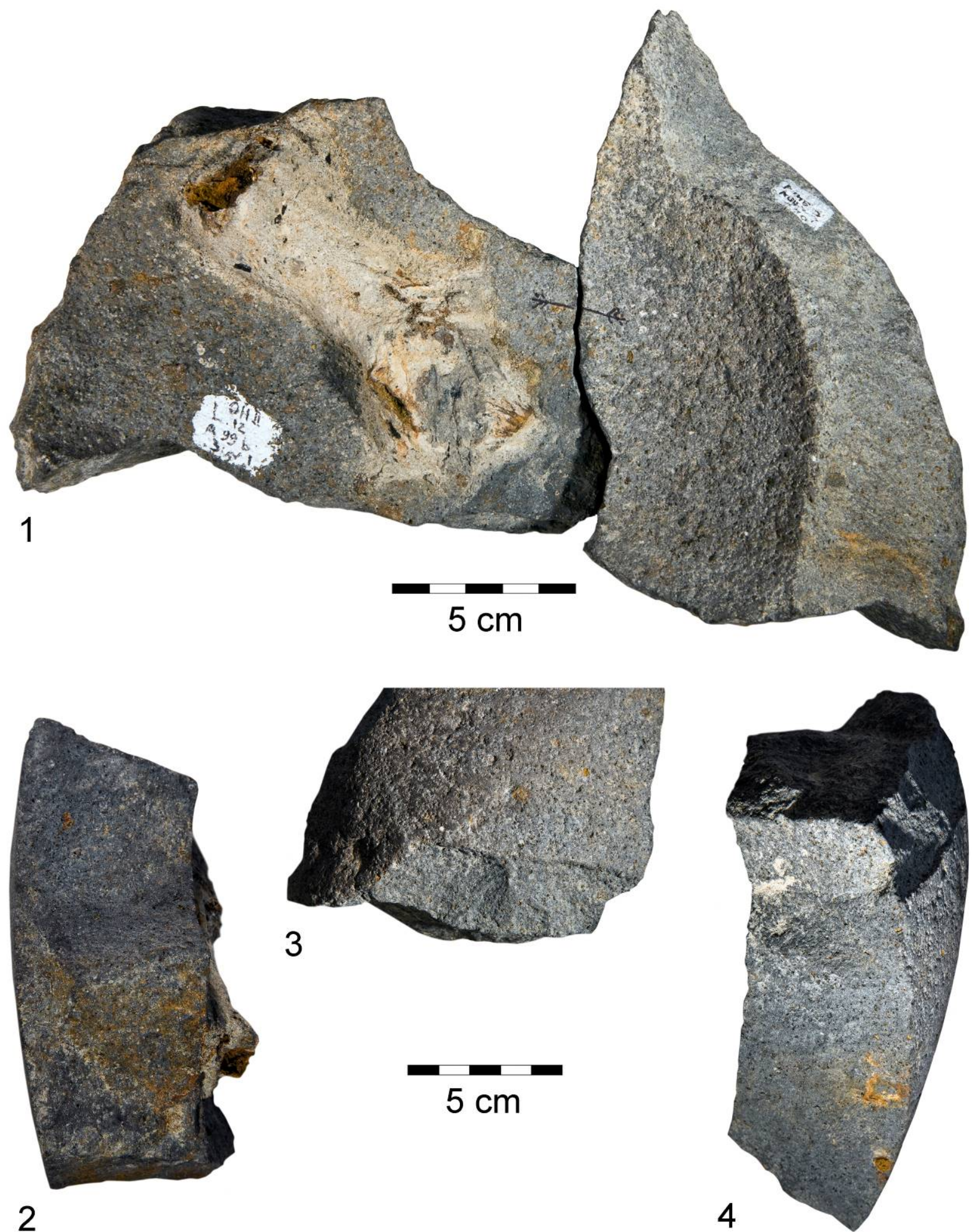

Figure 7. Two refitted fragments of a basalt bowl, Loc. 12. 1) top view, note the incrustation on the left fragment; 2, 4) the profiles of the two specimens; 3) two flaking scars on the edge of a fragment. 
Several basalt bowl fragments were flaked after breakage. One specimen was flaked all around by crude unidirectional blows (Figure 8). The piece is a fragment of the base of a shallow bowl, ca. $6 \mathrm{~cm}$ thick. The scars are 2-3 cm long and 1-2 cm wide. Furthermore, there are at least 10 impact marks along the edge.
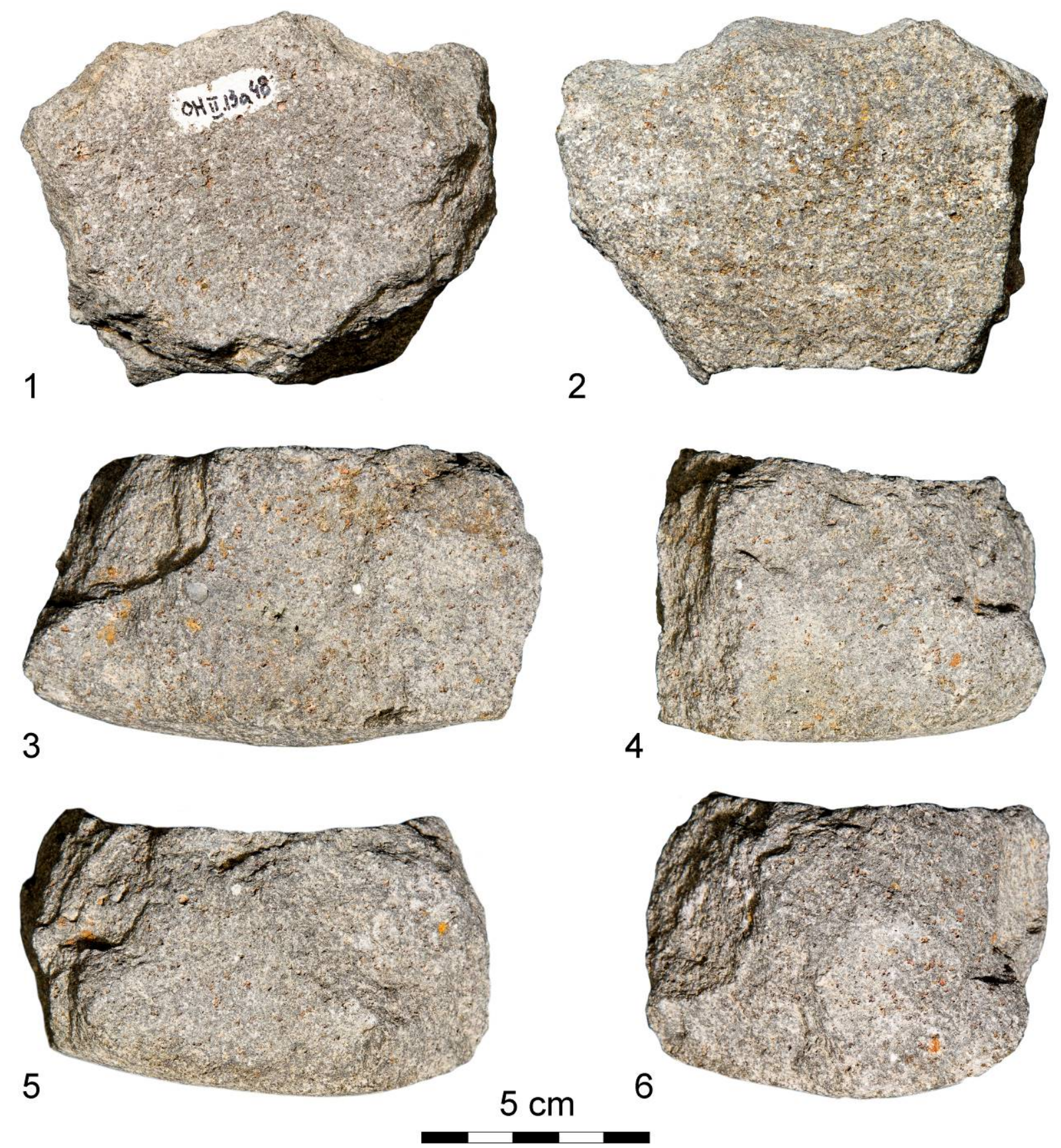

Figure 8. A base fragment of a basalt bowl. 1,2) top and bottom views; 3-6) side views with flake scars all around.

Similar stone bowls or vessels are extremely rare in contemporaneous or somewhat later Epipalaeolithic sites in the southern Levant (Wright 1994). For example, a couple of bowls were found associated with burials at Neve David (Kaufman 1989: fig. 2; Bocquentin et al. 2011: fig. 4). However, some other types of vessels are present in small numbers. For example, a deep basalt mortar was found at Ein Gev I (Bar-Yosef 1970: figs. 90, 97), and one vessel fragment was found at Azraq 17 (Wright 1992b: 638). 
Clearly, the bowls had great value as their manufacture level is much higher than performed for other types, and most of the fragments (even small pieces) were reused. Some were redesigned by flaking; others were recycled as wall supports (Loc. 12, below). Interestingly, except for one, all bowl fragments were found in brush huts.

\subsubsection{Grinding tools}

There are 17 grinding tools, divided into lower (stationary) and upper (movable) components (Kraybill 1977: 487). Most of them are hardly shaped, or not shaped at all. They were chosen according to size and shape, and by using those for grinding at least one face became smooth, usually with delicate striations visible by the naked eye.

\subsubsection{Lower tools}

Two grinding slabs were found. One boulder grinding slab (Wright 1992a:141; 1992b) was installed into the second floor of Brush Hut 1 (Figure 9). It was firmly set on a patch of sand and stabilized by several pebbles (Nadel 2003). The distribution of 12,000 cereal grains on the floor, mostly around it, strongly suggests that grinding took place here (Piperno et al. 2004; Weiss et al. 2008). Starch grains of wild wheat, wild barley and wild oats were retrieved from the top side of the stone, while they were rare on the bottom side and the nearby sediments (Nadel et al. 2012). Use-wear analysis indicates grinding, although not intensively (Dubreuil \& Nadel 2015).

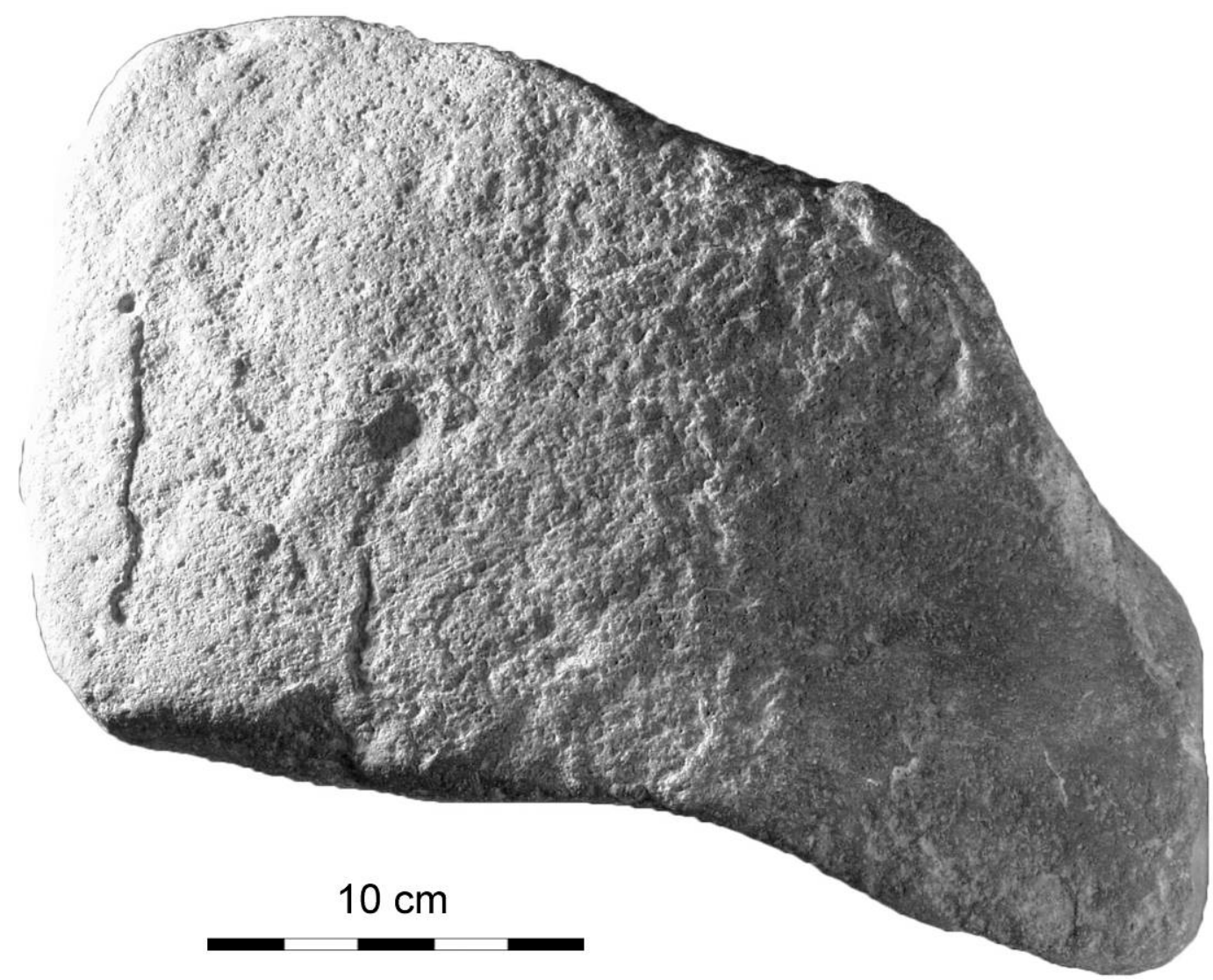

Figure 9. The grinding stone from Floor II, Loc. 1. Cereal starch grains were found on this stone, and charred cereal grains were found around it (see text for details).

Another grinding slab has a saddle-like shape. Broken into three pieces, it was placed together with 10 used handstones forming a round paved installation near a grave (Loc. 4; 
Figure 10). All tools were very thin, likely not amenable for further use (Cane 1989). Remains of charred seeds were recorded here, suggesting the installation was used for processing (maybe by heating) plant foods.
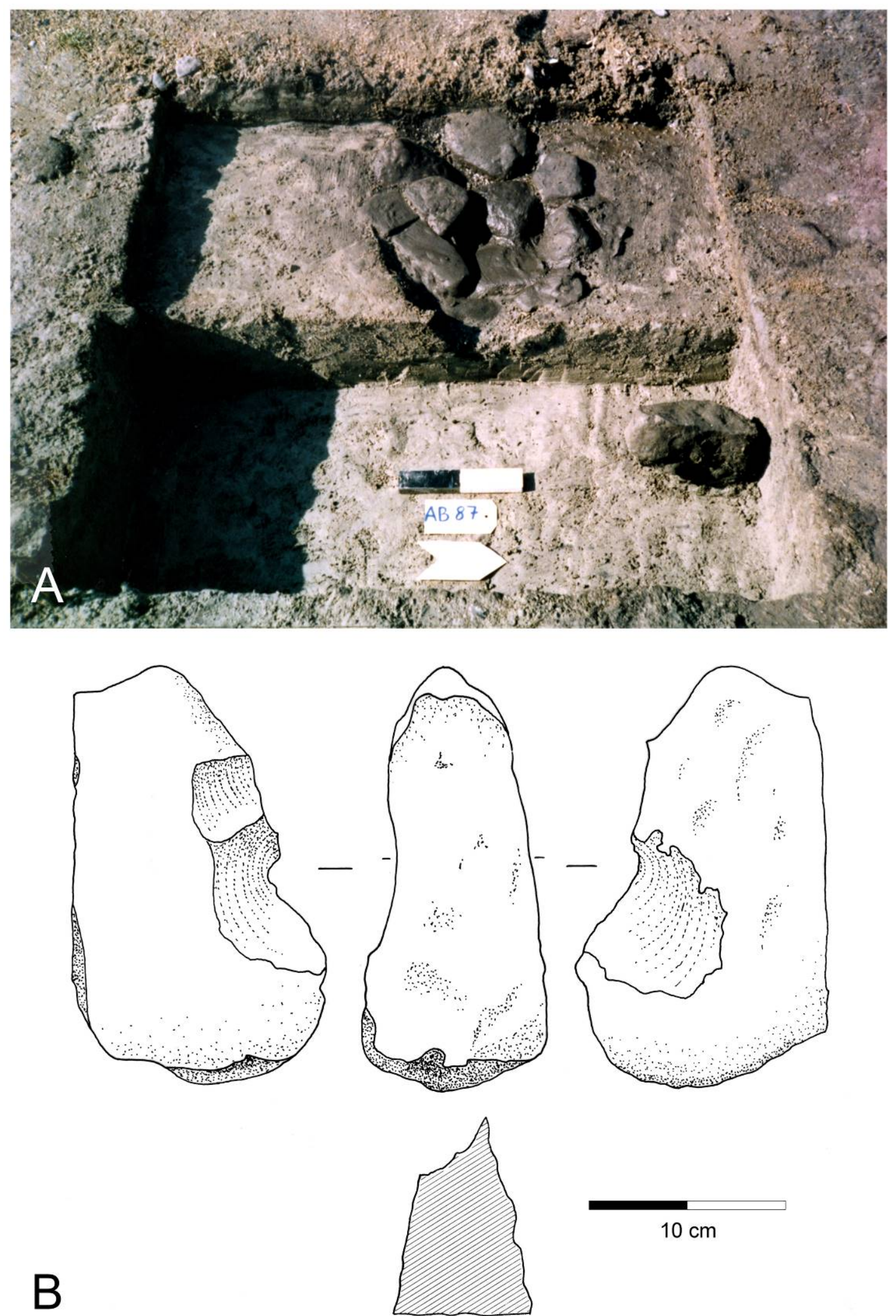

Figure 10. Loc. 4. a) a round feature composed of grinding tools, black and white scale $-20 \mathrm{~cm}$; b) an adjacent flaked stone set on edge (right). 


\subsubsection{Querns}

Fragments of three basalt basin querns (Wright 1992a:142 1992b) were found. Two of the querns were severely damaged by fire. The best preserved quern has an inner working surface, lower than the rim by $3 \mathrm{~cm}$.

Similar to the bowls, great pecking efforts were invested in the design of the querns. However, the querns were made from coarser, vesicular basalt with sporadic large pores. Unlike the bowls, the height and width of the rim is irregular though the inner base is flat and even.

\subsubsection{Upper tools}

All 12 upper tools (handstones) are made of basalt and are significantly smaller than the stationary ones (Table 3). These have one or two parallel faces suitable for grinding. In two cases the tools were shaped by pecking, polishing and delicate flaking, creating a rounded outline. One of these was made on a large flake and in both only one face was used as a working surface. Ten additional handstones were found installed in Loc. 4. All Loc. 4 specimens are unmodified natural stones shaped purely by grinding motion. Following Wright's (1992a; 1992b) definition, five are identified as bifacial oval/oval; three as bifacial sub-oval/lens; one bifacial oval-triangular / triangular; and one bifacial ovalrectangular/triangular. Stating the outline shape of the handstones may be misleading as the forms were not achieved by intentional design. The average length of the handstones (13.9 cm; Table 3) appears to be typical of pre-agricultural grinding tools (Adams 1999). As the thickness of all handstones (except for one) is below $4 \mathrm{~cm}$, it is possible that they were all exhausted (Cane 1989).

Table 3. Data and dimensions of 12 handstones. Abbreviations: STD - standard deviation; L - length; W - width; $\mathrm{T}$ - thickness.

\begin{tabular}{|c|c|c|c|c|c|c|c|}
\hline Tool type & Loc. & $\begin{array}{l}\text { Catalog. } \\
\text { Number }\end{array}$ & $\begin{array}{c}\text { Preservation } \\
\text { state }\end{array}$ & $\begin{array}{c}\text { Working } \\
\text { faces }\end{array}$ & $\mathbf{L}$ & $\mathbf{W}$ & $\mathbf{T}$ \\
\hline Handstone on flake & 22 & & complete & 2 & 7.5 & 7.5 & 2.5 \\
\hline Unifacial discoidal handstone & 23 & & fragment & 1 & & 11.0 & 4.0 \\
\hline Bifacial oval or oval & 4 & Oh II 4a4 & complete & 2 & 17.0 & 11.0 & 3.0 \\
\hline Bifacial oval or oval & 4 & Oh II $4 a 7$ & Fragment & 2 & & & 4.0 \\
\hline Bifacial oval or oval & 4 & Oh II 4a13 & complete & 2 & 15.0 & 10.0 & 3.0 \\
\hline Bifacial oval or oval & 4 & Oh II $4 a 8$ & complete & 2 & 16.0 & 13.0 & 2.0 \\
\hline Bifacial oval or oval & 4 & Oh II 4a12 & complete & 2 & 12.0 & 9.0 & 4.0 \\
\hline $\begin{array}{l}\text { Bifacial oval-triangular or } \\
\text { triangular }\end{array}$ & 4 & Oh II 4a11 & complete & 2 & 14.0 & 10.0 & 7.0 \\
\hline $\begin{array}{l}\text { Bifacial oval-rectangular or } \\
\text { triangular }\end{array}$ & 4 & Oh II 4a10 & complete & 2 & 17.0 & 13.0 & 4.0 \\
\hline Bifacial sub-oval or lens & 4 & Oh II 4a2 & complete & 2 & 13.0 & 9.0 & 2.0 \\
\hline Bifacial sub-oval or lens & 4 & Oh II 4a9 & fragment & 2 & & & 2.0 \\
\hline \multirow[t]{3}{*}{ Bifacial sub-oval or lens } & 4 & Oh II 4a6 & fragment & 2 & & 7.0 & 3.0 \\
\hline & & & & Average & 13.9 & 10.1 & 3.4 \\
\hline & & & & STD & 3.2 & 2.0 & 1.4 \\
\hline
\end{tabular}

\subsubsection{Multiple tools}

There are 13 multiple tools; most are actually handstones with one or more grinding faces and one or more additional working surface(s) for a non-grinding activity (e.g. pecking, 
percussion). Only one standard (Wright 1992a: 641) multiple tool was found (Figure 11). It was carefully shaped by pecking. Use-wear study (Dubreuil \& Nadel 2015) revealed signs of percussion, pounding and abrasion, most likely caused by processing hard minerals.
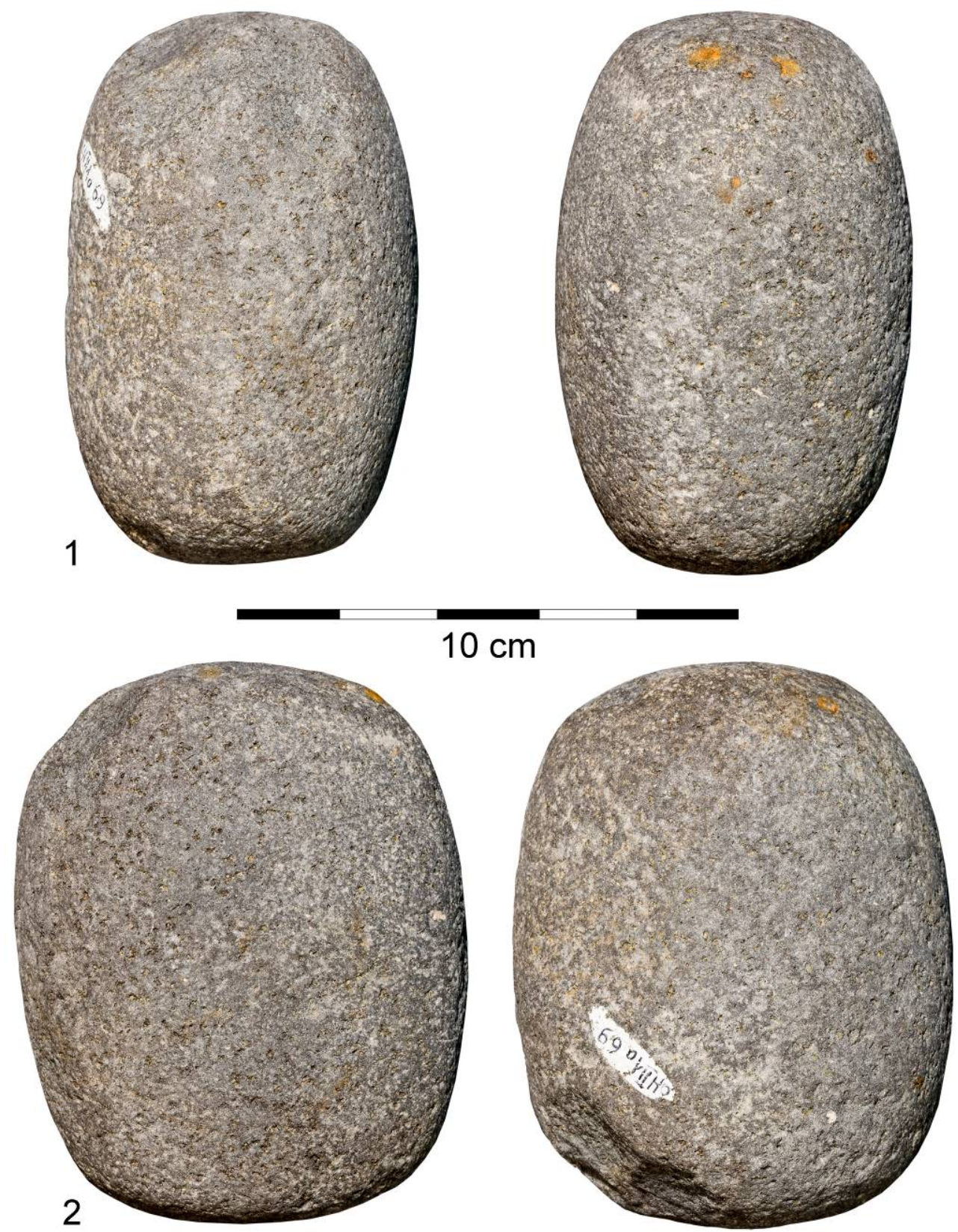

Figure 11. Basalt handstones used for two functions or more, hereby defined as multiple tools.

The other 12 implements included in this category are natural pebbles with multiple convenient working faces and edges covered by visible marks probably created by use. In fact, a final identification of most of the non-standard tools is still a subject for use-wear analysis.

\subsubsection{Fishing weights}

Altogether 53 pebbles with two opposite notches were found at the site (Table 4). Only 12 were retrieved from the excavated loci while the rest were collected from the surface (Nadel \& Zaidner 2002). However, it should be noted that such tools are extremely rare 
around the lake's shores according to our survey, while they were common on the surface of the Ohalo II site (see also Rosenberg et al. 2016). Furthermore, in terms of dimensions and technology they are identical to the in situ remains. It is thus concluded that they are part of the Ohalo II material remains.

The notches were fashioned on the long sides of the stone. They were usually prepared by flaking, pecking, or a combination of both (Figures 12-14). The notches are usually asymmetrical, in the sense that one is much larger than the other. Based on physical characteristics, ethnographical and archaeological examples, these double-notched pebbles were interpreted as net sinkers or fishing trap anchors (Nadel \& Zaidner 2002). This contention was supported by the presence of thousands of fish bones (Zohar 2002), as well as three tiny fragments of burnt cords (Nadel et al. 1994). Isolated specimens have a pecked groove all around (Figure 12: 2) and others have incisions on their backs (Figure 14: 2).

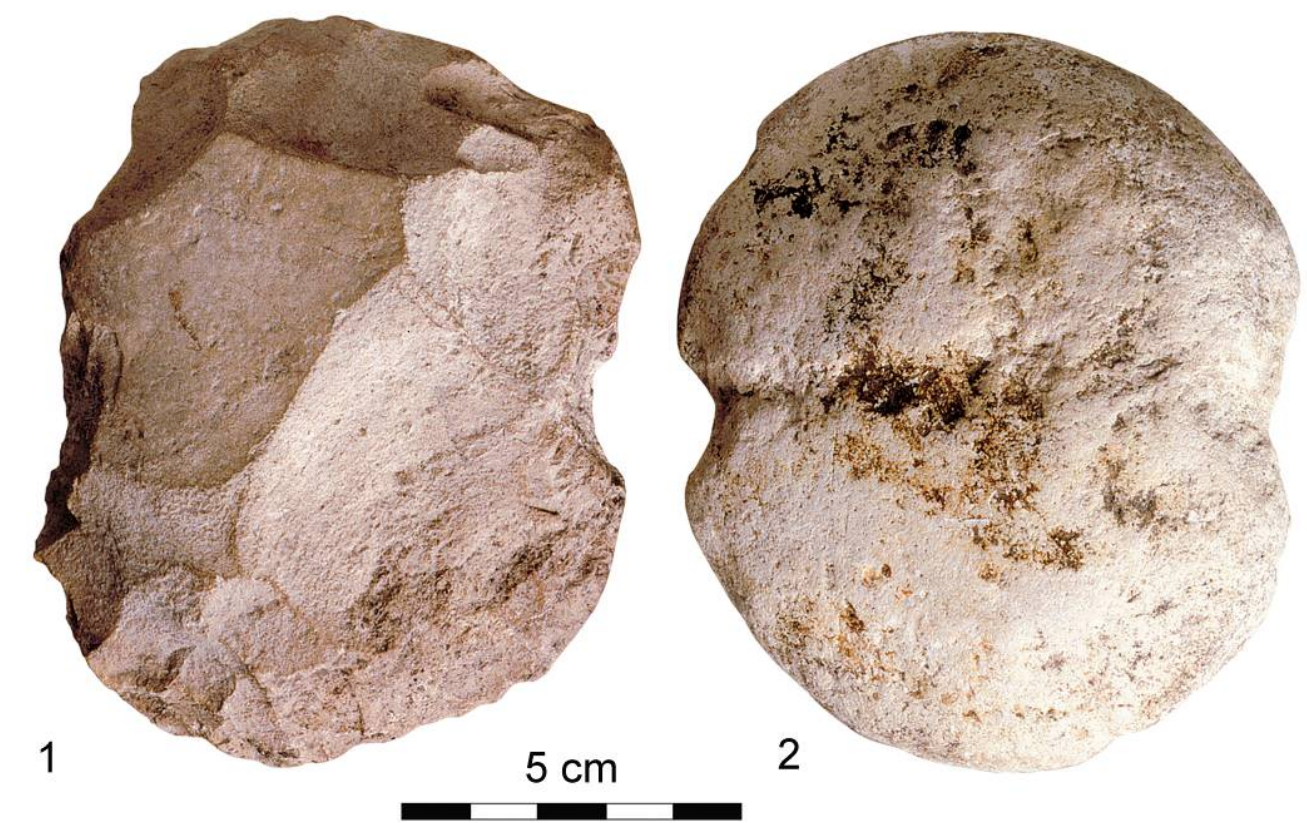

Figure 12. Stone weights made on limestone pebbles. Note the flake scars on 1 and the pecking evidence on the notches and across the implement on 2.
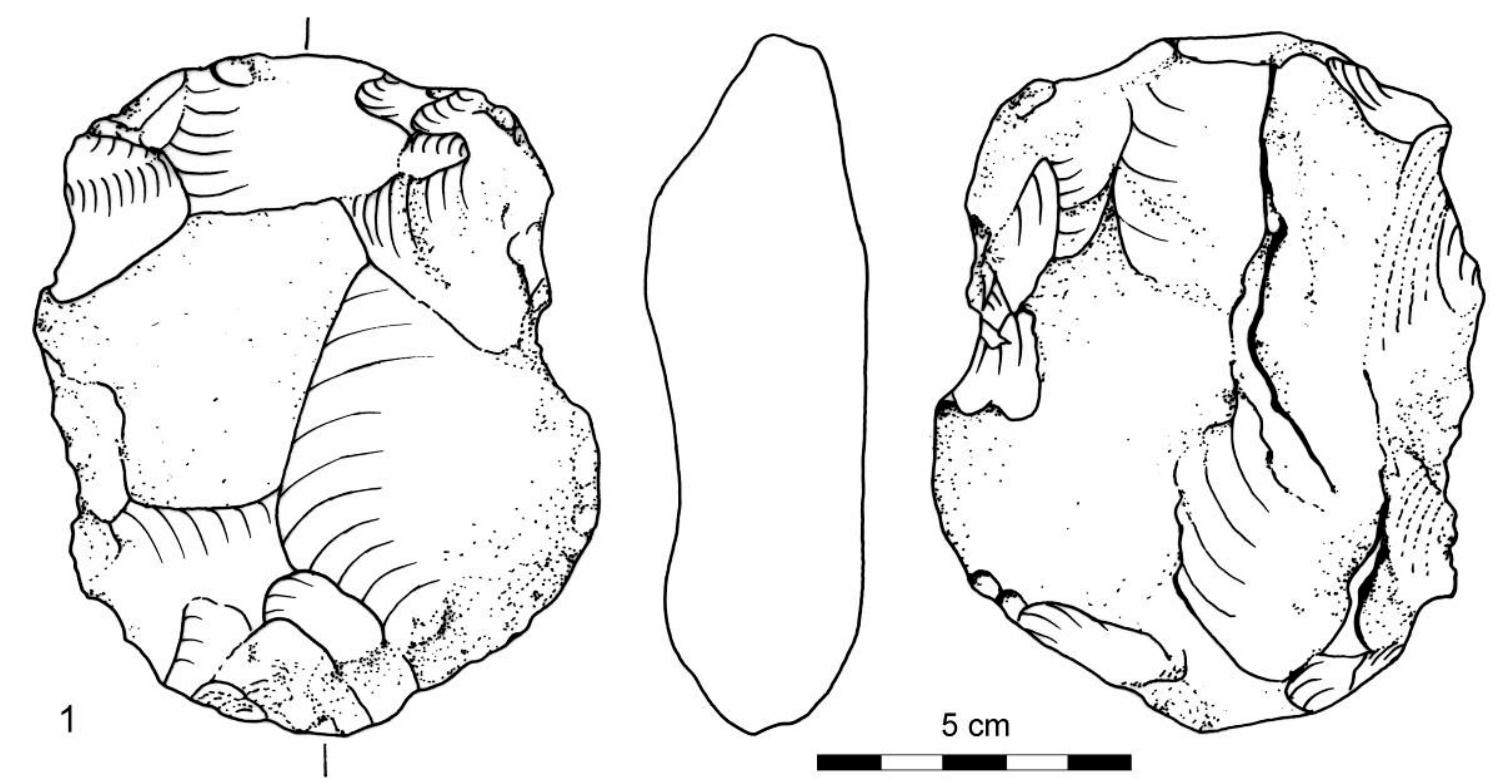

Figure 13. An example of a stone weight flaked on both sides (no. 1 in Figure 12). 

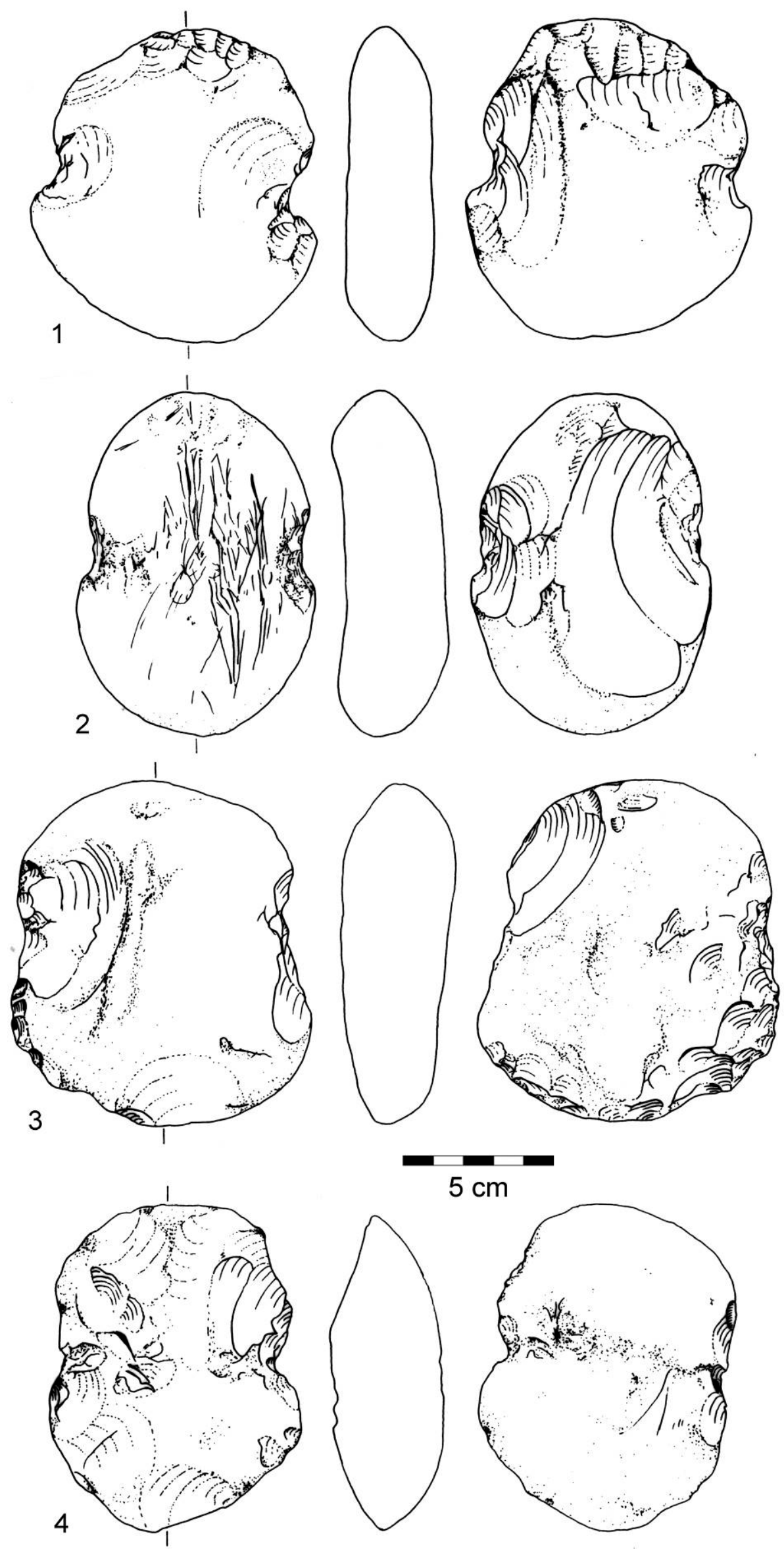

Figure 14. Stone weights from Ohalo II. Note the asymmetrical notches in all, and the incisions on specimen 2. 
Table 4. Average dimensions (cm) of double notched weights from Ohalo II. Abbreviations: Avg L - average length; Avg W - average width; Avg T - average thickness; N - number of samples.

\begin{tabular}{lllll}
\hline Sample & Avg L & Avg W & Avg T & N \\
\hline Ohalo II. Present study. Archaeological layer. & 10.3 & 8.3 & 3.0 & 6 \\
Ohalo II, archaeological layer (Nadel \& Zaidner 2002). & 9.6 & 7.7 & 3.4 & 6 \\
Ohalo II, surface collection (Nadel \& Zaidner 2002). & 11.1 & 8.5 & 3.7 & 41 \\
\hline
\end{tabular}

\subsubsection{Varia and fragments}

A range of tools and tool fragments that are too small or damaged to be assigned to a specific tool category is included in this group $(n=22)$. Half of the specimens are irregular shapes and exhibit somewhat uncertain macroscopic use-wear signs. However, one of these implements (OHII-1a57) was studied under the microscope and showed a micropolish typical of skin processing (Dubreuil \& Nadel 2015).

\subsection{Debitage}

Wright's category of debitage includes flakes and flake cores, pecked preforms and indeterminate spalls (Wright 1992: 143).

\subsubsection{Flakes}

So far 44 flakes were documented among the 1,712 stone artifacts that were thoroughly analyzed (Spivak 2008: 45-49). Although basalt dominates the general assemblage of stones and fragments (ca. 90\%), the majority of flakes were made of limestone (Figure 15). A third of all the flakes were found in Brush Hut 13, possibly indicating relatively intensive manufacturing or maintenance activities on this floor.

There is cortex on the dorsal side of 25 flakes, six of which have $100 \%$ cortex cover. Only 13 flakes are broken, and there are heat signs on 24. Most flakes are wide (average 4.8 $\mathrm{cm}$ ) and short (average $4.2 \mathrm{~cm}$ ), with 1-3 scars of previous flaking.

Two basalt flakes were set vertically under the bottom floor of Brush Hut 1, maybe as part of an inauguration rite or for other reasons (Nadel 2011: fig. 10). A set of selected and organized pebbles was also found under the same floor, maybe representing a human figure (Nadel 2006: figs. 7, 8).
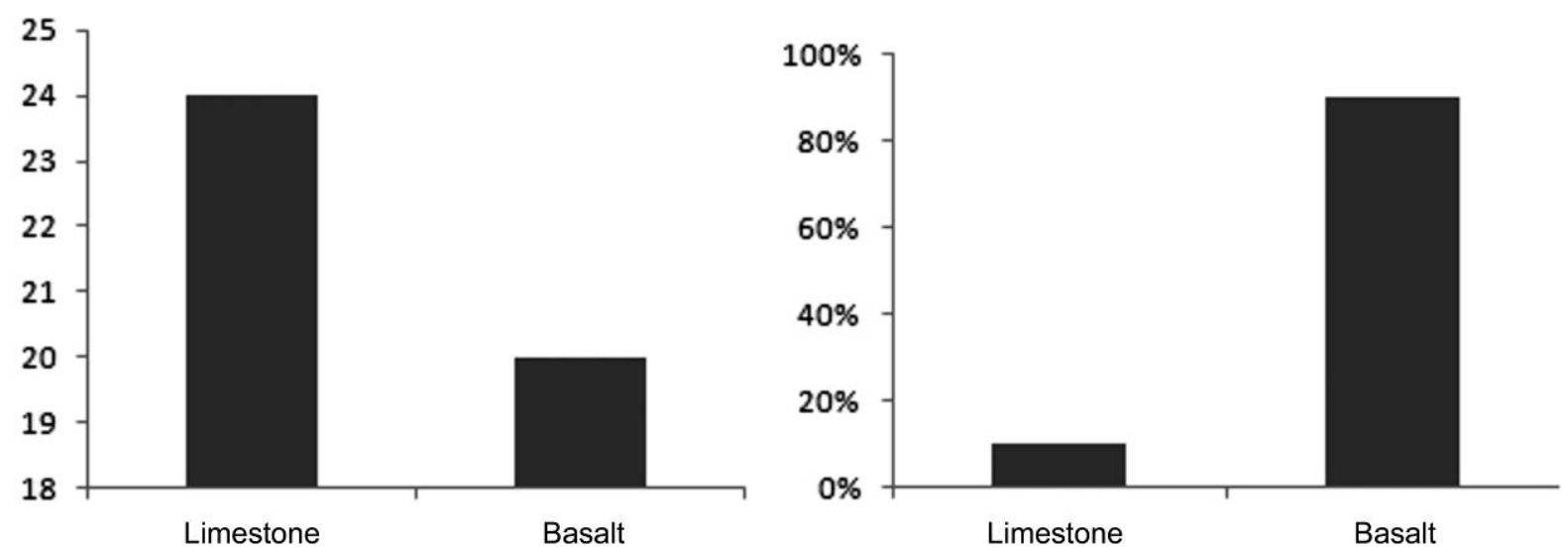

Figure 15. Frequencies of raw materials among flakes $(\mathrm{N}=44$, left) and among the total stone assemblage ( $N=20,872$, right). 


\subsubsection{Flaked stones}

Additional evidence of stone flaking is provided by implements with flake scars. Such scars are common on the weights with double notches and on bowl fragments (see above). Also, at the entrance to Brush Hut 1 there was a large basalt boulder (32 x $28 \times 17 \mathrm{~cm})$. There were several large scars on its face; some of the large removed flakes could have been used to shape the typical local weights or the smaller handstones (Figure 16). Three limestone pebbles and one basalt pebble have flaking scars. These may be unfinished weights that broke during manufacture.

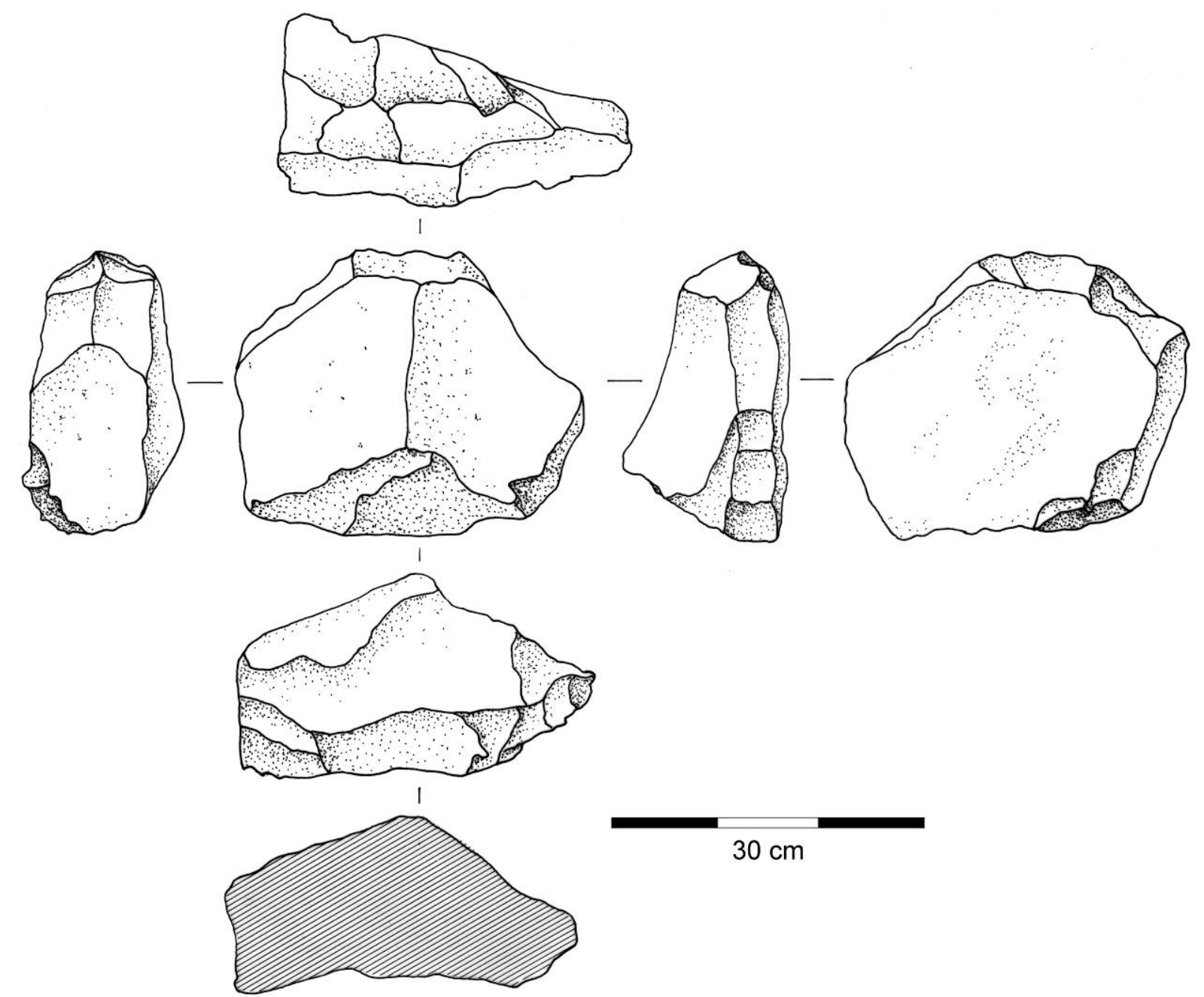

Figure 16. A flaked basalt boulder found by the entrance to Brush Hut 1, Floor II.

\subsection{Installations and wall supports}

\subsubsection{Installations}

The data presented in this section have been published before (Nadel 2003), and will thus only be summarized here.

Loc. 4 was described above, as it was constructed from 11 grinding tools (Figure 10). The lengths of the 10 handstones (range 12-17 cm, average $13.9 \mathrm{~cm}$ ) match the width of the accompanying grinding slab $(12 \mathrm{~cm})$ (Table 3$)$. Whether or not all specimens were part of one tool kit is unknown (Adams 1999). Nonetheless, the construction of a round feature from grinding implements, some broken and exhausted, may reflect more than a grinding location. The only such feature at Ohalo II was located next to a burial (1.5 m away). Furthermore, 
there was an adjacent flaked stone set on edge and a large blade placed by it, both in a northsouth orientation (Figure 10). Thus, it may be that the composition of the stone feature, and the association with the grave and the other components, were not functional in terms of daily activities (Nadel 2002). Rather, this complex embodied symbolic meanings to be understood within the social framework of the inhabitants. In later periods, as well as in many ethnographic cases, there is an association between food, food processing implements, and mortuary ritual (e.g. Grosman \& Munro 2007; Santana et al. 2015; see also Rosenberg 2013).

\subsubsection{Wall supports}

During the excavation of Brush Hut 12 small groups of stones and stone fragments were observed along the northern wall-line (Figure 17; Nadel 2003). They formed a loose arc along the northwestern edge of the hut; most of them are basalt stones. Most were placed in groups of two or three stones, $20-50 \mathrm{~cm}$ apart; one isolated boulder was set on edge (Figure 18). Notably, broken stone tools were also incorporated in this line. There were no additional stones and implements of similar size near this line, and thus it is believed that this was not a stone wall with some displaced stones. The dark floor sediment did not reach these stones (except for one group), and thus we conclude that the stones were placed around the outer perimeter of the hut, possibly to support thick diagonal wall stakes or the base of the brush hut. Isolated stones of similar dimensions were found adjacent to the walls-or inside the walls_ of Brush Huts 2 and 3 (Nadel 2003).

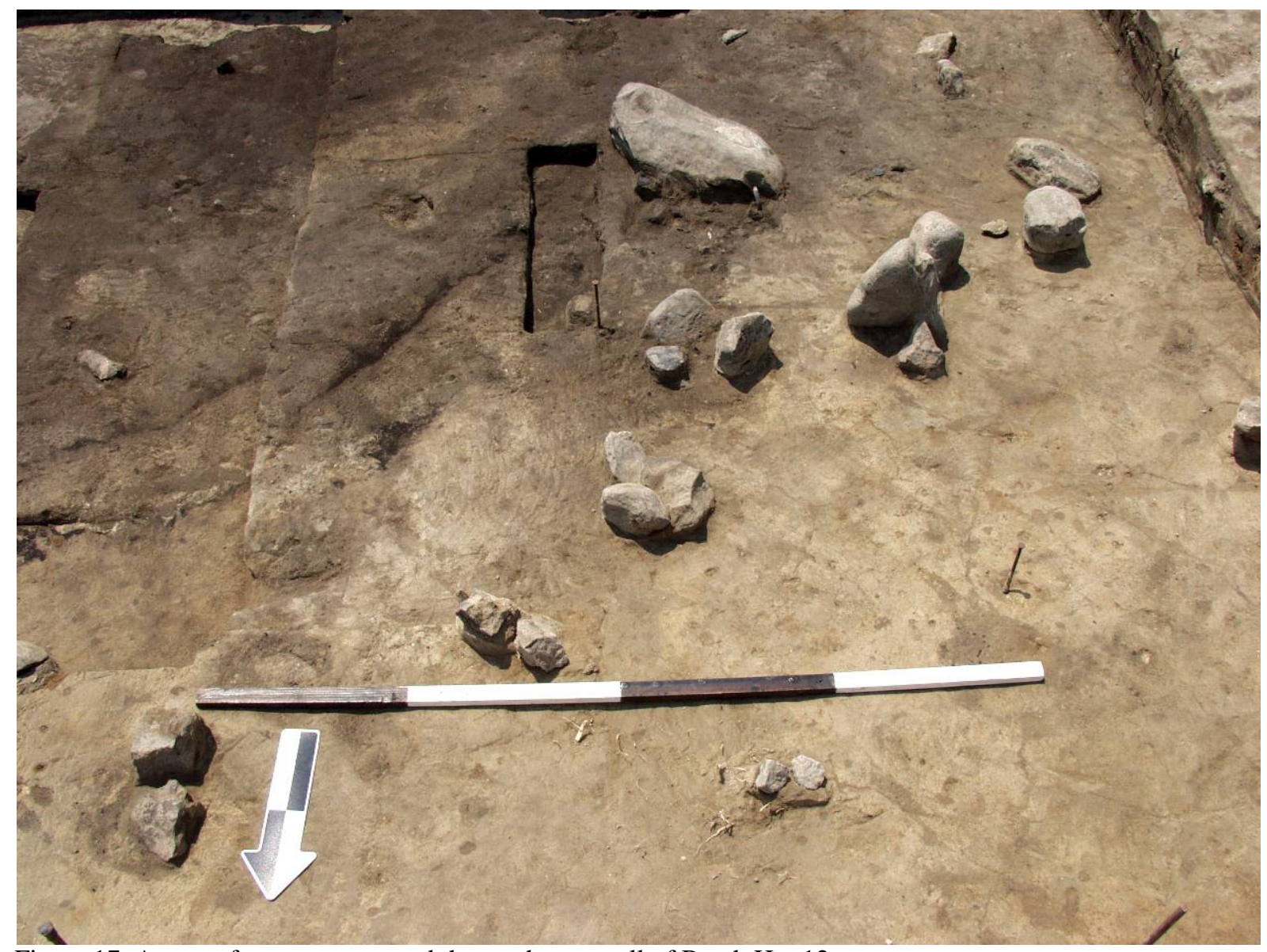

Figure 17. An arc of stone sets around the northwest wall of Brush Hut 12. 


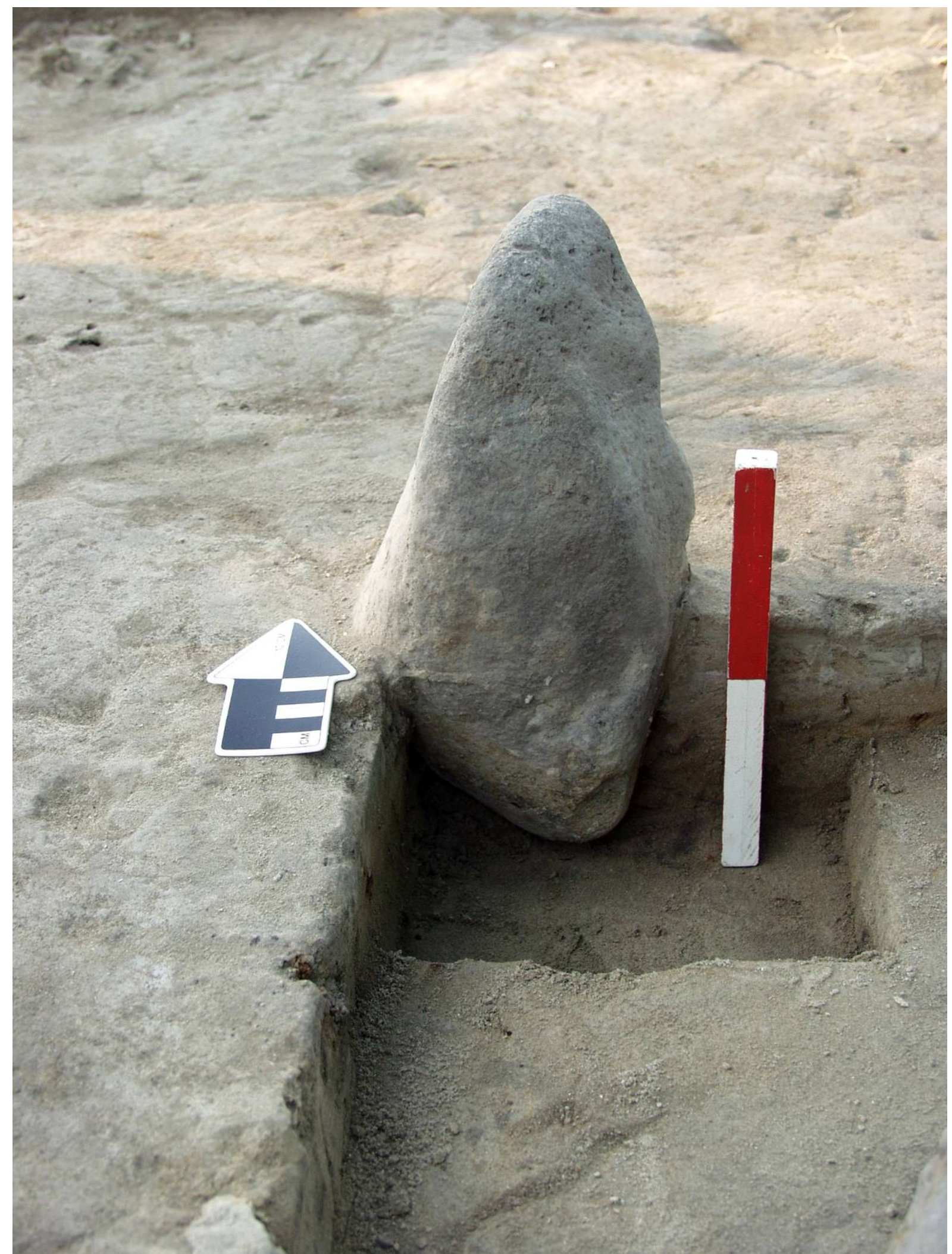

Figure 18. An isolated boulder set on edge within the arc of stones around the northwest wall of Brush Hut 12 (Figure 17). Vertical scale bar $20 \mathrm{~cm}$. 


\subsection{Stones and fragments}

The assemblage of natural stones (pebbles and boulders) and fragments was also analyzed (Spivak 2008: 49, 55-58). Complete pebbles and boulders as well as their fragments were found in all excavated loci $(n=150) ; 60 \%$ of all pebbles were concentrated in just two huts, reflecting human activities rather than natural deposition.

\subsubsection{Heat shattered fragments}

Fragments, of various dimensions, that could not be identified as tools, debitage or pebbles comprise $85 \%$ of the above-mentioned sample. The vast majority of fragments are flat and thin (tabular) with two parallel faces and roughly broken edges (Figure 19). Many fragments are similar in size and shape and have very sharp edges, indicating that they broke in situ, and due to the same process.

With the intention of understanding how such fragments were formed, a sequence of fire related experiments was conducted on the shore of the lake, not far from the site (Spivak 2008: 50-55). The experiments in open fire included stones from the vicinity of the site: a) basalt cobbles, ca. $12 \mathrm{~cm}$ in length, various levels of porosity; b) limestone cobbles, ca. $12 \mathrm{~cm}$ in length; c) basalt cobbles, ca. $20 \mathrm{~cm}$ in length, various levels of porosity; d) basalt boulders, $25 \mathrm{~cm}$ and longer.

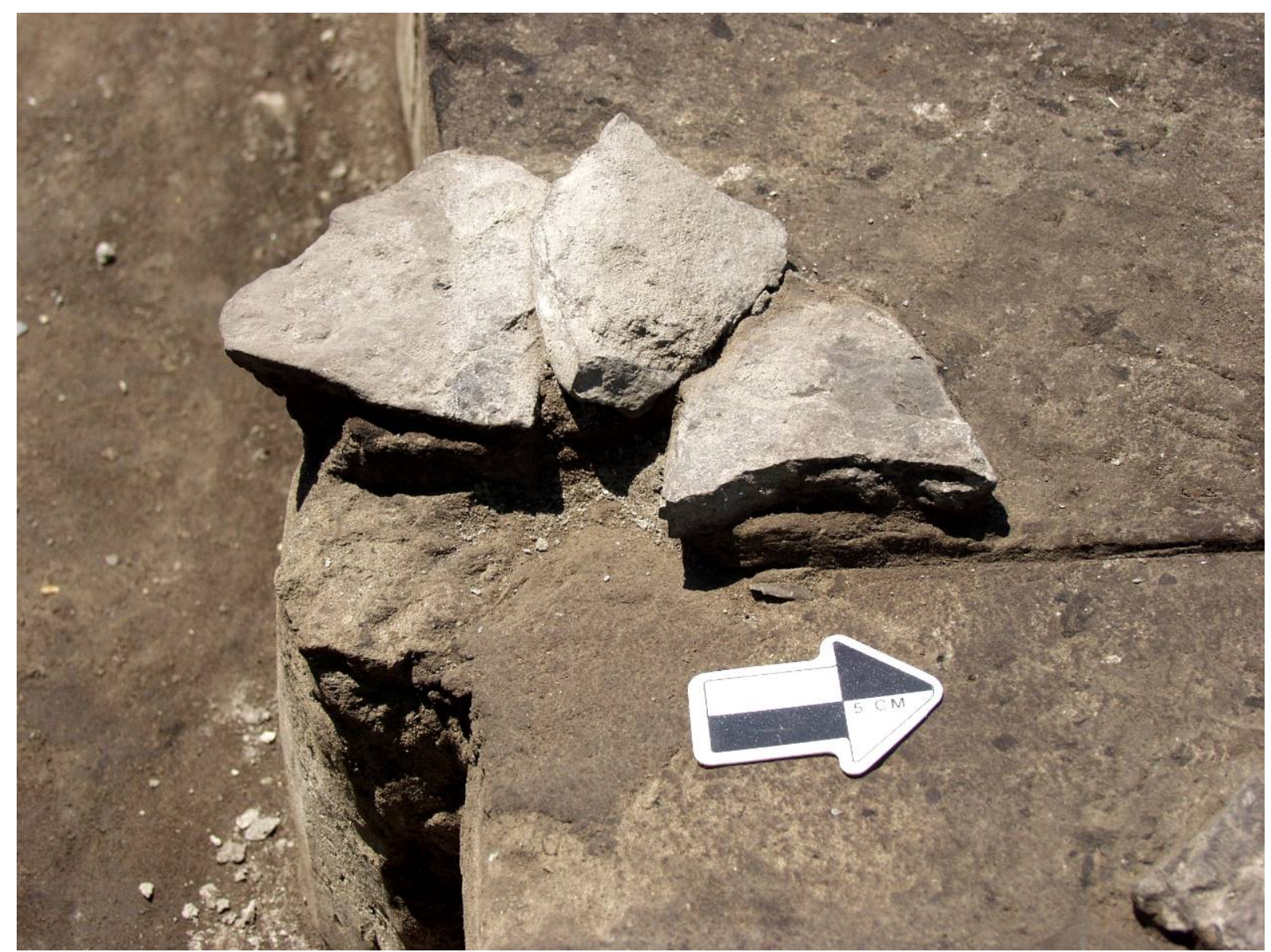

Figure 19. Flat thin basalt fragments, in situ as found. Scale arrow $5 \mathrm{~cm}$.

The stones were placed on a thin layer of dry branches and weeds, somewhat imitating the grass bedding found on the floor of Brush Hut 1 (Nadel et al. 2004). Additional branches were placed over the stones, representing a collapsed brush hut. Fire was maintained for 3-6 
hours. When flames became big, stones began to explode. Some pieces larger than $50 \mathrm{~mm}$ dispersed as far as $1.5 \mathrm{~m}$ from their original place, though some remained in place. The fire went out naturally. The stones and fragments (Figures 20 and 21) were then collected using a grid and a sieve, as was done for the archaeological site.

Several observations are relevant here: a) most fragments accumulated in the center of the fire; only a few pieces were dispersed. b) all specimens exposed to open fire broke into flat thin fragments (Figures 20 and 21) and small pieces; the original stone remained broken, cracked and with many fractured faces. Some stones transformed into a pile of flat thin fragments. c) no differences were recorded for basalt and limestone shattering. d) there were cases where all fragments remained adjacent to each other while in other cases the fragments dispersed and became mixed with fragments of other nearby stones. The same is true for the archaeological remains on some brush hut floors. e) the fragments from one basalt cobble (20 $\mathrm{cm}$ long) were collected and measured. The size distribution of the fragments is very similar to those documented for the archaeological finds (Figure 22). f) stone explosion began within a few minutes of direct exposure to flames. However, a slow warming of the stones did not cause explosion. Accordingly, in places like hearths, where fire is controlled and heating is slow, lining stones would not commonly explode.

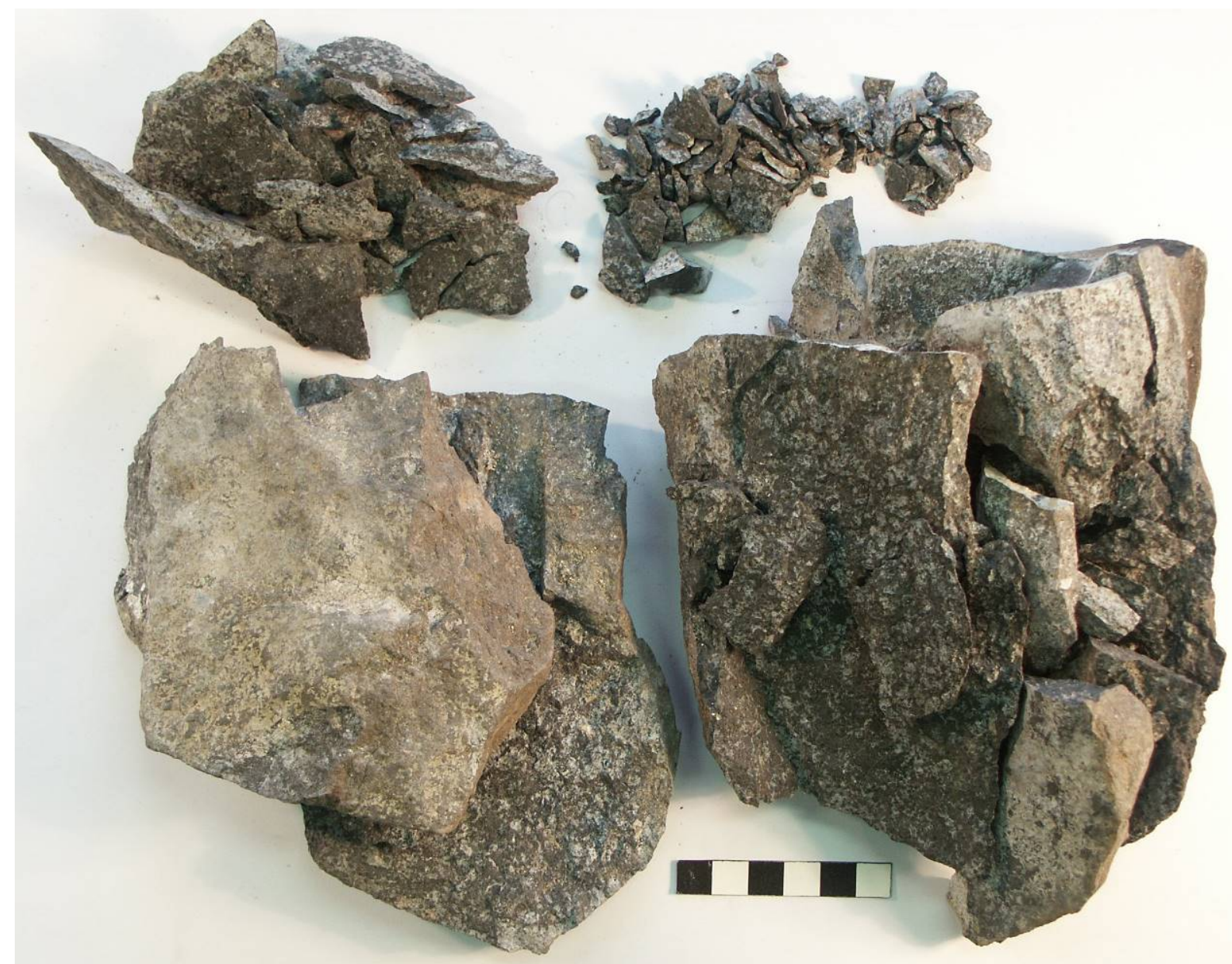

Figure 20. Fragments of experimental heat shattered basalt. Note the flat thin specimens. Scale in $\mathrm{cm}$. 


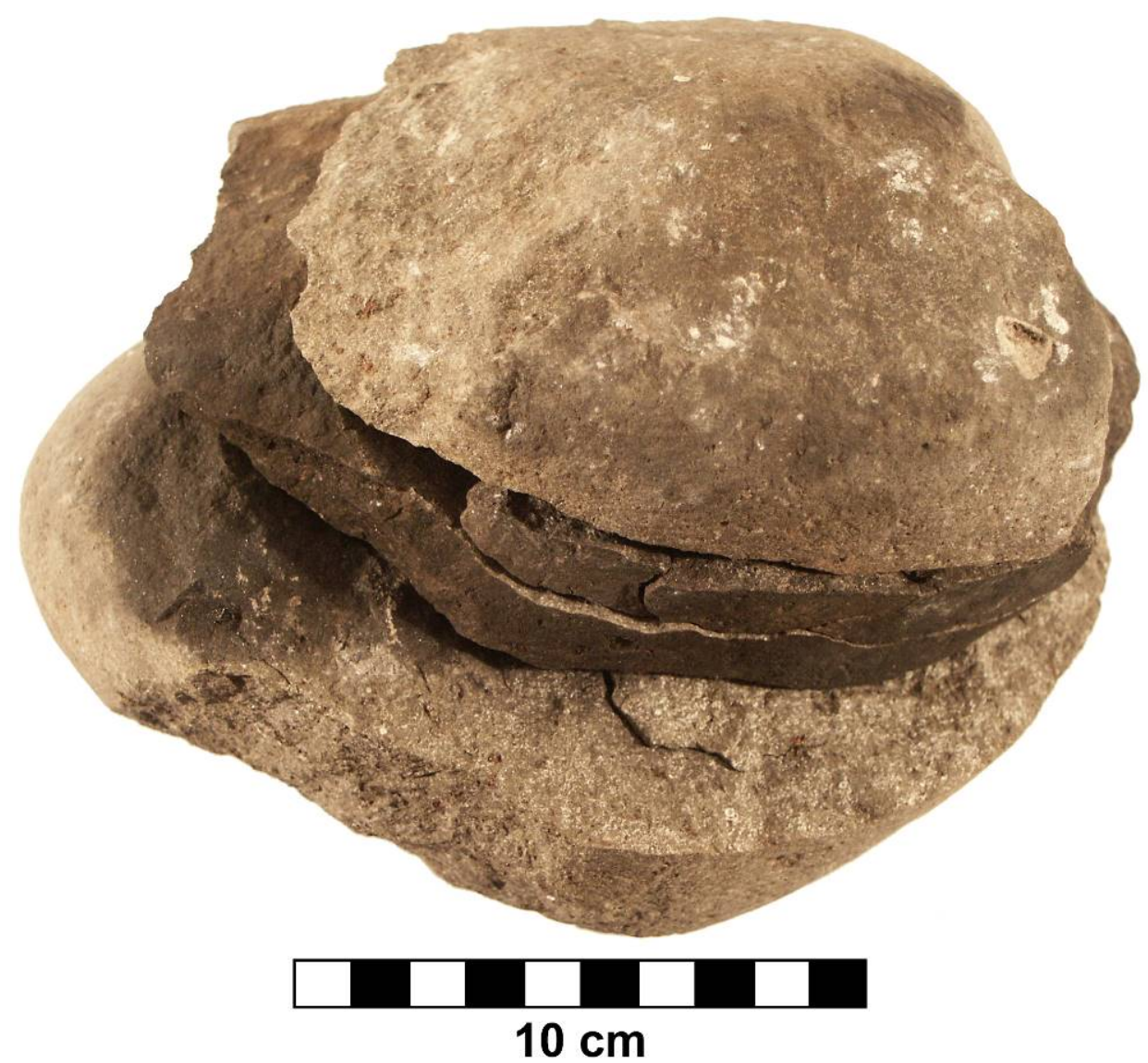

Figure 21. Refitted fragments of experimental heat shattered limestone.

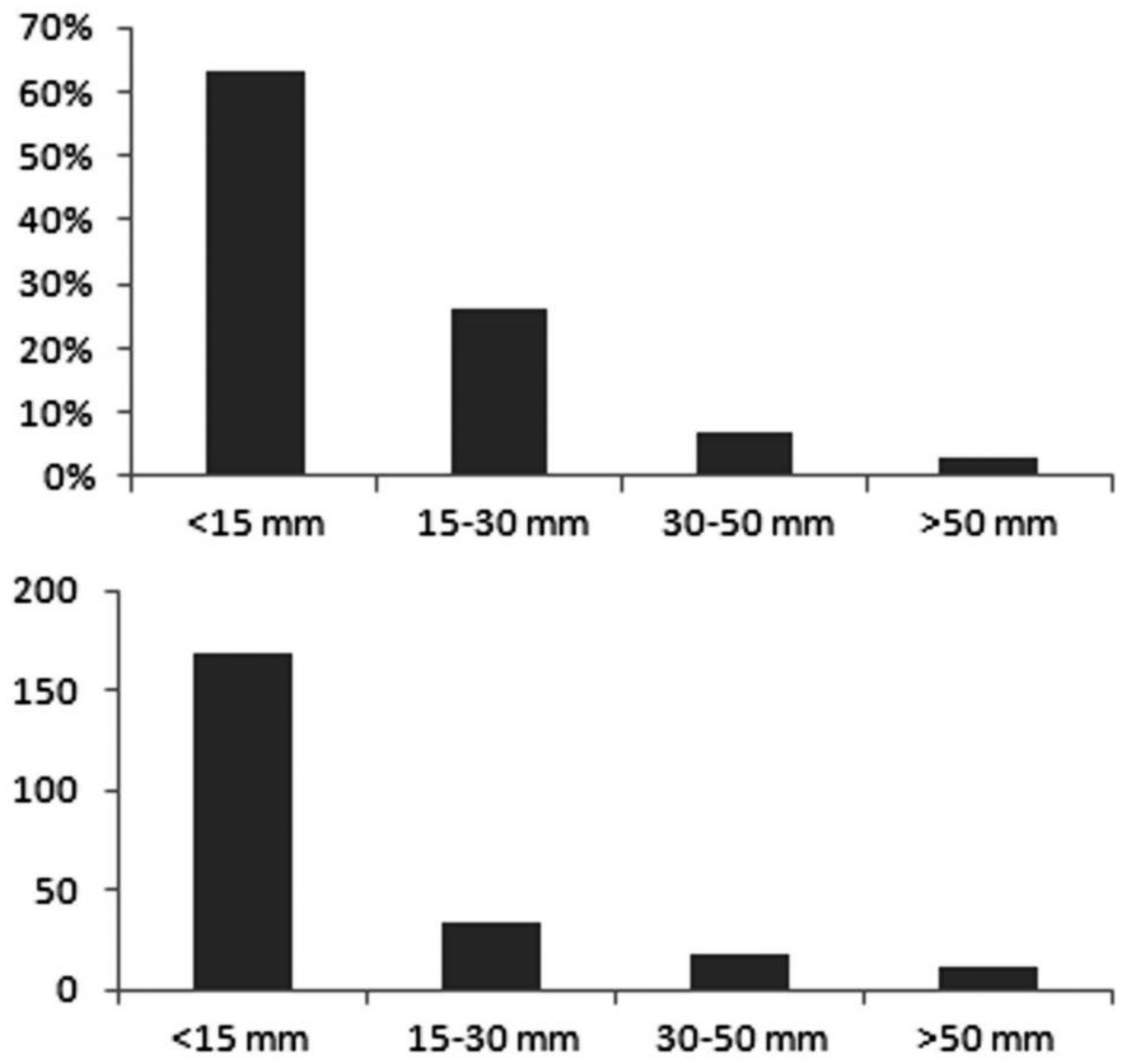

Figure 22. Size distribution of experimental (top) and archaeological (bottom) fragments. 
The wealth of heat shattered fragments on the floors of brush huts reflects the presence of many stones, mostly basalt, on these floors. They may have been used for a variety of tasks, including food cooking. It is suggested that most of them exploded when the brush huts burned down. Burnt bones and burnt flints were found on the same floors, though no particular clusters were identified. The archaeological data suggests that all the excavated brush huts were burned, either unintentionally or more likely, deliberately.

\section{Interpretations of the data}

The use of stone at Ohalo II was common and in a wide range of realms. In terms of subsistence patterns, two aspects are particularly noteworthy. One is the evidence for cereal grinding, both in terms of lower and upper tools, as well as their in situ preservation. However, all such tools represent minimal investment in shaping the implements. In addition, according to use-wear analysis, they were not used intensively (Dubreuil \& Nadel 2015). This may suggest that many were used ad-hoc and then discarded, outside the camp and thus only a small number were found. Alternatively, cereal grinding wasn't a major activity at the site, as may be suggested by the very small number of sickle blades (Snir et al. 2015b). Both explanations are considered viable at this stage.

The second aspect concerns the double-notched pebbles, interpreted as net sinkers. These, the most common ground stone tools at the site, reflect fishing in the lake. That such activity was important and that fish were an essential component of the diet is clear based on the large numbers of fish bones on brush hut floors and around fireplaces (Zohar 2002; 2003).

In terms of workmanship quality, the bowls reflect the highest investment in shaping the implements. Interestingly, all bowl remains are of shallow vessels, likely usable not only as containers but also as confined working surfaces. All specimens are fragments, each one much smaller than half a bowl. Two were heavily incised and buried up-side-down into floors. In addition, two sets of conjoinable fragments were retrieved, but even in these cases most fragments of each bowl are missing. As such, and following ethnographic examples and archaeological studies in other continents, the patterns observed here are interpreted as reflections of cognitive behavior where grinding implements were deliberately broken, and then components were buried on site and distributed beyond, following social codes and traditions (Chapman 2000; Chapman \& Gaydarska 2007; Adams 2008; Dubreuil \& Nadel 2015). This may also be supported by the possible burial of basalt flakes under the floor and the setting of selected flints and animal bones in particular arrangements (Nadel 2000; 2003; 2006).

The presence of basalt and limestone flakes in various dimensions reflects local manufacture or maintenance of ground stone tools. Limestone dominance among flakes may reflect the common on-site manufacture of tools while basalt was mostly worked elsewhere. Several types, like the weights and the reworked bowl fragments, have flake scars. In most reports of Late Upper Palaeolithic - Early Epipalaeolithic sites in the southern Levant, no presentation or discussion of flakes and manufacturing by flaking are available (e.g. Wright 1994).

Comparisons of the major ground stone types found at Ohalo II to other contemporaneous sites in the southern Levant are limited, due to the scarcity of such finds (Wright 1994). A few examples are discussed. Bowls were not reported from contemporaneous sites. However, a few were found at the Geometric Kebaran site of Neve David, two in direct association with burials (Kaufman 1989: fig. 2; Bocquentin et al. 2011: fig. 4). One shallow wide bowl, similar to the Ohalo II bowls, was reported from Haon III, a Geometric Kebaran site across the lake from Ohalo II (Bar-Yosef 1975: fig. 2C). Other types of containers or vessels were reported from some sites. For example, a basalt mortar with 
steep walls was found at Ein Gev I, inside a hut and likely associated with a burial (Bar-Yosef 1970: figs. 90, 97). A small rim fragment was recovered from an in situ deposit at the Kebaran site of Azraq 17 in Jordan (Wright 1992b: 197, Tables 4-5).

Grinding tools were somewhat more common at the time. Isolated implements were reported even from sites in the Negev, such as Ein Aqev, where a basalt specimen is about 12 $\mathrm{cm}$ long and a little concave at the top (Marks 1976: fig. 9.28, top). Natural slabs and stones used for grinding, in essence similar to the Ohalo II specimens, were reported from Upper Palaeolithic sites across Europe (Aranguren et al. 2007; Revedin et al. 2010, 2014).

Stone weights, pebbles with a pair of opposed notches, were not reported from most contemporaneous sites in the region. Some well-shaped similar specimens, termed bifacial axes, were found at Nazlet Khater 4, an Upper Palaeolithic site in Egypt (Vermeersch et al. 1984; 1990). In the southern Levant, pebbles with a pair of opposed notches appear again in the Natufian site of Eynan, though the specimens are smaller than those found at Ohalo II (Valla et al. 1999).

Thus, although the Ohalo II assemblage of ground stone tools is small relative to the size of the excavated site, the grinding tools, the bowls and the weights there are very few contemporaneous assemblages for comparison. It is possible, however, that the size of the recordable ground stone tool assemblage was affected by destructive fire events, and originally there were more tools.

The large numbers of burnt fragments, supported by our experimental work, indicates that stones were common in many parts of the camp, including on brush hut floors; their original use is yet to be verified. The use of stone at the camp includes additional aspects. Supports for walls are present at least for one brush hut, although true stone walls were not present in the region at that time. This should be taken as an important point in terms of architecture developments and innovations at the region, as Ohalo II was occupied year-round and boulders were available in the vicinity of the site (Nadel 2003; Goring-Morris \& BelferCohen 2008). Yet, again, stone walls or even stone foundations were not constructed. Stone features, such as an installation made of grinding tools, are rare and become common only in the Natufian.

\section{Acknowledgements}

The Ohalo II project was generously supported by the Irene Levi-Sala CARE Archaeological Foundation, the Israel Antiquities Authority, the Israel Science Foundation, the Jerusalem Center for Anthropological Studies, the L.S.B. Leakey Foundation, the MAFCAF Foundation, the National Geographic Society and the Stekelis Museum of Prehistory in Haifa. M. Eisenberg photographed Figures 20 and 21, and D. Maayan photographed Figures 5-8 and 11. A. Regev-Gisis made the digital designs.

\section{References}

Adams, J. L. 1999, Refocusing the role of food-grinding tools as correlates for subsistence strategies in the U. S. Southwest. American Antiquity, 64(3): 475-498. doi:10.2307/2694147

Adams, J. L. 2002, Ground Stone Analysis: A Technological Approach. University of Utah Press, Salt Lake City, 336 p.

Adams, J. L. 2008, Beyond the broken. In: New Approaches to Old Stones, (Rowan, Y., \& Ebeling, J., Eds.), Equinox Publishing, London: p. 213-229. 
Aranguren, B., Becattini, R., Lippi, M.M., \& Revedin, A. 2007, Grinding flour in Upper Palaeolithic Europe (25000 years bp). Antiquity, 81: 845-855.

doi:10.1017/s0003598x00095946

Bar-Yosef, O. 1970, The Epipalaeolithic Cultures of Palestine. Unpublished Ph.D. dissertation, Archaeology Department, The Hebrew University of Jerusalem, Jerusalem, $260 \mathrm{p}$.

Bar-Yosef, O. 1975, Les gisements "Kébarien Géométrique A" d'Haon, Vallée du Jourdain, Israël. Bulletin de la Société préhistorique française, 72(1): 10-14. (in French) ("The Geometric Kebaran A site of Haon III, the Jordan Valley, Israel”). doi:10.3406/bspf.1975.4392

Bocquentin, F., Crevecoeur, I., Arensburg, B., Kaufman, D. \& Ronen, A., 2011, Les hommes du Kébarien géométrique de Neve David, Mont Carmel (Israël). Bulletin et Mémoires de la Société d'Anthropolgie de Paris, 23: 38-51. (in French) (“Geometric Kebaran Site of Neve David, Mount Carmel (Israel)”). doi:10.1007/s13219-010-0032-9

Cane, S. 1989, Australian aboriginal seed grinding and its archaeological record: a case study from the Western Desert. In: Foraging and Farming: the Evolution of Plant Exploitation, (Harris, D. R., \& Hillman, G. C., Eds.), Unwin Hyman, London: p. 99119.

Chapman, J. 2000, Fragmentation in archaeology. London, UK, Routledge, 264 p. doi:10.4324/9780203759431

Chapman, J., \& Gaydarska, B. 2007, Part and Wholes. Fragmentation in Prehistoric Context. Oxford, UK, Oxbow Books, 233 p.

Dubreuil, L., \& Nadel, D. 2015. The development of plant food processing in the Levant: insights from use-wear analysis of Early Epipalaeolithic ground stone tools. Philosophical Transactions of the Royal Society B, 370: 20140357. doi:10.1098/rstb.2014.0357.

Goring-Morris, A.N., \& Belfer-Cohen, A. 2008, A roof over one’s head: Developments in Near Eastern residential architecture across the Epipalaeolithic-Neolithic transition. In: The Neolithic Demographic Transition and its Consequences, (Bocquet-Appel, J.P., \& Bar-Yosef, O., Eds.), Springer Netherlands: p. 239-286. doi:10.1007/978-1-4020-85390_10

Grosman, L., \& Munro, N.D. 2007. The sacred and the mundane: Domestic activities at a Late Natufian burial site in the Levant. Before Farming, 4: 1-14. doi:10.3828/bfarm.2007.4.4

Kaufman, D. 1989, Observations on the Geometric Kebaran: A view from Neve David. In: Investigations in South Levantine Prehistory, (Bar-Yosef, O., \& Vandermeersch, B., Eds.), BAR International Series Vol. 497, Archaeopress, Oxford: p. 275-285.

Kraybill, N. 1977, Pre-agricultural tools for the preparation of foods in the Old World. In: Origins of Agriculture, (Reed, C., Ed.), Mouton, The Hague: p. 485-522. doi:10.1515/9783110813487.485

Marks, A.E. 1976, Ein Aqev: a late Levantine Upper Palaeolithic site in the Nahal Aqev. In: Prehistory and Palaeoenvironments in the Central Negev, Israel, Vol. 1, The Avdat/Aqev Area, Part 1, (Marks, A.E., Ed.), SMU Press, Dallas: p. 227-291.

Nadel, D., (Ed.), 2002, Ohalo II - a 23,000 Year-Old Fisher-Hunter-Gatherers' Camp on the Shore of the Sea of Galilee. Hecht Museum, Haifa, 64 p. 
Nadel, D. 2003, A long continuity: the Ohalo II brush huts (19.5 ky) and the dwelling structures in the Natufian and PPNA sites in the Jordan Valley. Archaeology, Anthropology and Ethnology in Euroasia, 13(1): 34-48.

Nadel, D. 2006, Residence ownership and continuity: from the Early Epipalaeolithic unto the Neolithic. In: Domesticating Space, Construction, Community, and Cosmology in the Late Prehistoric Near East, (Banning E.B., \& Chazan, M., Eds.), Studies in Early Near Eastern Production, Subsistence and Environment Vol. 6. Ex-oriente, Berlin: p. 25-34.

Nadel, D. 2011, Stones in their symbolic context: Epipalaeolithic - Pre-Pottery Neolithic continuity in the Jordan Valley. In: The State of the Stone. Terminologies, Continuities and Contexts in Near Eastern Lithics, (Healey, E., Campbell, S., \& Maeda, O., Eds.), Studies in Early Near Eastern Production, Subsistence, and Environment Vol. 13, Exoriente, Berlin: p. 481-490.

Nadel, D., Belitzky, S., Boaretto, E., Carmi, I., Heinemeier, J., Werker E., \& Marco, S. 2001, New dates from submerged late Pleistocene sediments in the Sea of Galilee, Israel. Radiocarbon, 43(3): 1167-1178.

URL: https://journals.uair.arizona.edu/index.php/radiocarbon/article/view/3864/

Nadel, D., Carmi, I., \& Segal, D. 1995, Radiocarbon dating of Ohalo II: archaeological and methodological implications. Journal of Archaeological Science, 22(6): 811-822. doi:1016/0305-4403(95)90010-1

Nadel, D., Danin, A., Werker, E., Schick, T., Kislev, M.E., \& Stewart, K. 1994, 19,000 yearsold twisted fibers from Ohalo II. Current Anthropology, 35(4): 451-458. doi:10.1086/204303

Nadel, D., Grinberg, U., Boaretto, E., \& Werker, E. 2006, Wooden objects from Ohalo II (23,000 cal BP), Jordan Valley, Israel. Journal of Human Evolution, 50(6): 644-662. doi:10.1016/j.jhevol.2005.12.010

Nadel, D., Piperno, D.R., Holst, I., Snir, A., \& Weiss, E. 2012, New evidence of processing wild cereal grains at Ohalo II, a 23,000 year-old campsite on the shore of the Sea of Galilee, Israel. Antiquity, 86: 990-1003. doi:10.1017/s0003598x00048201

Nadel, D., Weiss, E., Simchoni, O., Tsatskin, A., Danin, A., \& Kislev, M.E. 2004, Stone age hut in Israel yields world's oldest evidence of bedding. Proceedings of the National Academy of Science, 101(17): 6821-6826. doi:10.1073/pnas.0308557101

Nadel, D., \& Werker, E. 1999, The oldest ever brush hut plant remains from Ohalo II, Jordan Valley, Israel (19 BP). Antiquity, 73(282): 755-764. doi:10.1017/S0003598X00065509

Nadel, D., \& Zaidner, Y. 2002, Upper Pleistocene and Mid-Holocene net sinkers from the Sea of Galilee, Israel. Journal of the Israel Prehistoric Society, 32: 49-71.

Piperno, D. R., Weiss, E., Holset I., \& Nadel, D. 2004, Processing of cereal grains in the Upper Palaeolithic revealed by starch grain analysis. Nature, 430: 670-673. doi:10.1038/nature02734

Rabinovich, R., \& Nadel, D. 2005, Broken mammal bones: taphonomy and food sharing at the Ohalo II submerged prehistoric camp. In: Archaeozoology of the Near East VI, Proceedings of the Sixth International Symposium on the Archaeozoology of Southwestern Asia and Adjacent Areas, (Buitenhuis, H., Choyke, A.M., Martin, L., Bartosiewicz, L., \& Mashkour, M., Eds.), ARC-Publicaties 123, Groningen: p. 34-50. 
Revedin, A., Aranguren, B., Becattini, R., Longo, L., Marconi, E., Mariotti Lippie, M., Skakun, N., Sinitsyn, A., Spiridonova, E., \& Svoboda, J.2010, Thirty thousand-year-old evidence of plant food processing. Proceedings of the National Academy of Sciences, 107(4): 18815-18819. doi:10.1073/pnas.1006993107

Revedin, A., Longo, L., Marconi, E., Mariotti Lippie, M., Marconi, E., Ronchitelli, A., Svoboda, J., Anichini, E., Gennai, M., \& Aranguren, B. 2014, New technologies for plant food processing in the Gravettian. Quaternary International, 359-360: 77-88. doi:10.1016/j.quaint.2014.09.066

Rosenberg, D. 2013. Not 'just another brick in the wall?' the symbolism of groundstone tools in Natufian and Early Neolithic southern Levantine constructions. Cambridge Archaeological Journal, 23(2): 1-17. doi:10.1017/s095977431300022x

Rosenberg, D., Agnon, M. and Kaufman, D. 2016. Conventions in fresh water fishing in the prehistoric southern Levant: The evidence from the study of Neolithic Beisamoun notched pebbles. Journal of Lithic Studies, 3(3): 457-478. doi:10.2218/jls.v3i3.1639

Santana, J., Velasco, J., Balbo, A., Iriarte, E., Zapata, L., Teira, L., Nicolle, C., Braemer, F., \& Ibáñez, J.J. 2015. Interpreting a ritual funerary area at the Early Neolithic site of Tell Qarassa North (South Syria, Late 9th Millennium BC). Journal of Anthropological Archaeology, 37: 112-127. doi:10.1016/j.jaa.2014.12.003

Snir, A., Nadel, D., Groman-Yaroslavski, I., Melamed, Y., Sternberg, M., Bar-Yosef, O., \& Weiss, E. 2015(a), The origin of cultivation and proto-weeds, long before Neolithic farming. PlosOne, 10(7): e0131422. doi:10.1371/journal.pone.0131422

Snir, A., Nadel, D., \& Weiss, U. 2015(b), Plant-food preparation on two consecutive floors at Upper Paleolithic Ohalo II, Israel. Journal of Archaeological Science, 53: 61-71. doi:10.1016/j.jas.2014.09.023

Spivak, P. 2008, Limestone and Basalt Assemblage from the Epipaleolithic Site of Ohalo II, a 23,000 Years Old Fisher-hunter-gatherers' Camp. Unpublished MA thesis, Archaeology Department, University of Haifa, Haifa, 83 p.

Tsatskin, A., \& Nadel, D. 2003, Formation processes at the Ohalo II submerged prehistoric campsite, Israel, deduced from soil micromorphology and magnetic susceptibility studies. Geoarchaeology, 18(4): 409-432. doi:10.1002/gea.10069

Valla, F.R., Bocquentin, F., Plisson, H., Khalaily, H., Delage, C., Rabinovitch, R., Samuelian, N., Valentin, B., \& Belfer-Cohen, A. 1999, Le Natoufien final et les nouvelles fouilles à Mallaha (Eynan), Israel 1996-1997. Journal of the Israel Prehistoric Society, 28: 105176. (in French) ("The Final Natufian and the renewed excavation at Mallaha (Eynan)”)

Vermeersch, P. M., Paulissen, E., Gijselings, G., Otte, M., Thoma, A., \& van Peer, P. 1984, 33,000-yr old chert mining site and related Homo in the Egyptian Nile Valley. Nature, 309(5966): 342-344. doi:10.1038/309342a0

Vermeersch, P. M., Paulissen, E., \& Van Peer, P. 1990, Palaeolithic chert exploitation in the limestone stretch of the Egyptian Nile Valley. African Archaeological Review, 8(1): 77102. doi:10.1007/bf01116872

Weiss, E., Kislev, M. E., Simchoni, O., Nadel, D., \& Tschauner, H. 2008, Plant-food preparation area on an Upper Paleolithic brush hut floor at Ohalo II, Israel. Journal of Archaeological Science, 35(8): 2400-2414. doi:10.1016/j.jas.2008.03.012 
Wright, K. 1991, The origins and development of ground stone assemblages in Late Pleistocene Southwest Asia. Paléorient, 17(1): 19-43. doi:10.3406/paleo.1991.4537

Wright, K. 1992a, A classification system for ground stone tools from the prehistoric Levant. Paléorient , 18(2): 53-81. doi:10.3406/paleo.1992.4573

Wright, K. 1992b, Ground Stone Assemblage Variations and Subsistence Strategies in the Levant, 22,000 to 5,500 B.P. Ph.D. dissertation, Anthropology Department, Yale University, University Microfilms International, Ann Arbor, 696 p.

Wright, K. 1994, Ground-stone tools and hunter-gatherer subsistence in Southwest Asia: Implications for the transition to farming. American Antiquity, 59(2): 238-263. doi:10.2307/281929

Wright, K. 2014, Domestication and inequality? Households, corporate groups and food processing tools at Neolithic Çatal Höyük, Journal of Anthropological Archaeology, 33: 1-33. doi:10.1016/j.jaa.2013.09.007

Zohar, I. 2002, Fish and fishing at Ohalo II, In: Ohalo II, a 23,000 year-old Fisher-HunterGatherers' Camp on the Shore of the Sea of Galilee, (Nadel, D., Ed.), Hecht Museum, Haifa: p. 28-31.

Zohar, I. 2003. Fish Exploitation at the Sea of Galilee (Israel) by Early Fisher-HunterGatherers (23,000 B.P.): Ecological, Economical, and Cultural Implications. Unpublished Ph.D. dissertation, Department of Zoology, Tel Aviv University, 222 p. 